\title{
CONSUMER CAPTURE AND THE LEGAL SERVICES ACT 2007
}

\author{
Tim Sinnamon*
}

\section{INTRODUCTION}

It is now nearly 7 years since the Legal Services Act 2007 (LSA) ${ }^{1}$ was brought onto the statute books. ${ }^{2}$ It is now 5 years since the major provisions of the Act became effective. ${ }^{3}$ For those unfamiliar with the Act, it is a blockbuster piece of legislation ${ }^{4}$ which in its entirety runs to 214 sections (covering 120 pages) and 24 Schedules which make up the remainder of the total 389 pages. The LSA 2007 sought to fundamentally recalibrate the regulation of the legal services market. To achieve this, the Act introduced a new tier of oversight regulation, above the then existing regulators of legal services. ${ }^{5}$ This new oversight regulator, called the Legal Services Board (LSB) is armed with an arsenal of statutory powers. The LSA 2007 also established a new ombudsman in the form of the Office of Legal Complaints. ${ }^{6}$ Potentially the most contentious change brought about by the LSA 2007 was that it paved the way for new methods of practising law, ${ }^{7}$ including, Alternative Business Structures

* Dr Tim Sinnamon, BA(Hons), PgDip, LLM PgCAP, PhD, FHEA, Lecturer in Law, Buckingham Law School, University of Buckingham, Buckingham, MK18 1EG. Email: tim.sinnamon@buckingham.ac.uk.

${ }^{1}$ Legal Services Act 2007 (LSA 2007).

2 Ibid. Received Royal Assent on the 30 October 2007.

3 The Legal Services Board came into being on the 1 January 2009. It became fully operational on the 1 January 2010.

4 James Thorne and Ian Miller, Guide to the Legal Services Act (Lexis Nexis 2009).

5 Now termed 'Approved Regulators': The Law Society, The General Council of the Bar, The Master of Faculties, The Chartered Institute of Legal Executives, The Chartered Institute of Patent Attorneys, The Institute of Trade Mark Attorneys, The Association of Law Costs Draftsmen; The Council for Licensed Conveyancers.

${ }^{6}$ LSA 2007, pt 6.

7 Ibid pt 5. It should be noted that Legal Disciplinary Partnership and Multidisciplinary Partnership were previously provided for, in a limited way, in the Administration of Justice Act 1986 and the Courts and Legal Services Act 1992, though no steps were substantively taken to develop them. 
(ABS) which, when fully developed will allow for what were commonly referred to as multi-disciplinary practices, and much more. Currently the authorised regulators of $\mathrm{ABS}^{8}$ permit non-lawyers to own legal service providers and many more permutations of ownership and service delivery than hitherto existed. At the time of writing $290^{9}$ ABS have been authorised and regulated by the Solicitors Regulatory Authority since 26 March 2012. $43 \mathrm{ABS}^{10}$ have been authorised and are regulated by the Council for Licensed Conveyancers since 6 October 2011. IPReg ${ }^{11}$ who regulates for and on behalf of CIPA ${ }^{12}$ and ITMA $^{13}$ were approved by the Ministry of Justice ${ }^{14}$ and the LSB to regulate ABS in December 2013. The Bar announced on 27 June 2014 that it will move towards entity licencing, though they have signalled that this will fall short of full ABS. ${ }^{15}$ The Institute of Chartered Accountants in England and Wales (ICAEW) was recommended to the Lord Chancellor by the LSB in December 2013 to be accepted as an approved regulator for Probate and as a licensing authority for ABS. The Lord Chancellor approved of this on the 6 March 2014 paving the way for ICAEW to become the first non-legal body to be able to regulate probate services and licence ABS. ${ }^{16}$ ICAEW received assent to regulate probate activities and licence ABS on the 14 August $2014 .{ }^{17}$

${ }^{8}$ Ibid pt 5.
9 'Register of Licensed Bodies (ABS)' (Solicitors Regulation Authority)
<http://www.sra.org.uk/absregister/> accessed 29 July 2014.
${ }^{10}$ 'Licensed Body (ABS) Register' (Council for Licensed Conveyancers)
<http://www.conveyancer.org.uk/absregister.php> accessed 29 July 2014.
${ }^{11}$ Intellectual Property Regulation Board.
${ }^{12}$ Chartered Institute of Patent Attorneys.
${ }^{13}$ Institute of Trade Mark Attorneys.
${ }^{14}$ Neil Rose, 'IPReg Poised to Become Licensing Authority Number 3' (Legal Futures, 10 December 2013) <http://www.legalfutures.co.uk/latest-news/ipregpoised-become-abs-licensing-authority-number-3> accessed 24 July 2014.

${ }^{15}$ Catherine Baksi, 'Bar Regulator Announces Move into Entity Licensing' (Law Society Gazette, 27 June 2014) <http://www.lawgazette.co.uk/practice/ipregauthorised-to-regulate-abs-entities/law/bar-regulator-announces-move-into-entitylicensing/5041910.article> accessed 14 August 2014; Nick Hilborne, 'Barristers Lay Out Plans for Range of New Entities' (Legal Futures, 1 July 2014) $<$ http://www.legalfutures.co.uk/latest-news/barristers-lay-out-plans-range-newentities> accessed 14 August 2014.

${ }^{16}$ Neil Rose, 'Grayling Gives Accountants ABS and Probate Green Light' (Legal Futures, 7 March 2014) <http://www.legalfutures.co.uk/latest-news/graylinggives-accountants-abs-probate-green-light $>$ accessed 15 August 2014.

${ }^{17}$ Gazette Reporter, 'ICAEW Approved to Regulate Probate and License ABS' (Law Society Gazette, 14 August 2014) 
These developments signal profound change and it is for this reason that this paper examines, in part, the way in which regulation of the legal services market is done. In particular it considers the regulatory objectives included in the LSA 2007. ${ }^{18}$ The regulatory objectives run through the LSA 2007 like the lettering in a stick of rock. There are over thirty substantive references to the regulatory objectives in the Act. Far from being a passive declaration of the purpose of the Act, the regulatory objectives underpin the statutory obligations of the $\operatorname{LSB}^{19}$ and the approved regulators. ${ }^{20}$ The LSB, the approved regulators, and the OLC ${ }^{21}$ are all obliged to act in a way that they consider appropriate for meeting the regulatory objectives. ${ }^{22}$ The $\mathrm{LSB}^{23}$ and the OLC ${ }^{24}$ need to prove how they have met the regulatory objectives in their annual reports. The LSB has a considerable range of powers, including: setting approved regulators performance targets, ${ }^{25}$ directions regarding actions that need to be taken, ${ }^{26}$ censuring approved regulators, ${ }^{27}$ giving intervention directions allowing for the removal of a regulatory function from an approved regulator, ${ }^{28}$ and, most dramatically, removing an approved regulators licence to regulate. ${ }^{29}$ Each of the foregoing powers rests on the LSB's determination as to how the approved regulators' actions or omissions have affected one or more of the regulatory objectives.

$<$ http://www.lawgazette.co.uk/practice/icaew-approved-to-regulate-probate-andlicense-abss/5042605.article> accessed 15 August 2014.

${ }^{18}$ LSA 2007, pt 1, s 1.

${ }^{19}$ Ibid s 3(2)(a).

${ }^{20}$ Ibid s 28(2)(b).

${ }^{21}$ Ibid s 118(2)(b).

22 The Regulatory Objectives are: (a) protecting and promoting the public interest; (b) supporting the constitutional principle of the rule of law; (c) improving access to justice; (d) protecting and promoting the interests of consumers; (e) promoting competition in the provision of services within subsection (2); (f) encouraging an independent, strong, diverse and effective legal profession; (g) increase public understanding of the citizen's legal rights and duties; (h) promoting and maintaining adherence to the professional principles.

${ }^{23}$ LSA 2007, s 6(2)(b).

${ }^{24}$ Ibid s 118(2)(b).

${ }^{25}$ Ibid s 31(2)(a).

${ }^{26}$ Ibid s 32(4).

${ }^{27}$ Ibid s 35.

${ }^{28}$ Ibid s 41(1).

${ }^{29}$ Ibid s 45. 
The importance attached to understanding what each regulatory objective means is undeniable. Regulators and administrative authorities are often charged with making complex judgements. In the context of the LSA 2007, individual objectives, within a broad spectrum of regulatory objectives, need to be rationalised, by the regulators, with each other. These regulatory objectives, for reasons outlined throughout this paper, and others, ${ }^{30}$ set the course for the regulation of legal services.

The introduction of regulatory objectives into the LSA 2007 was by no means an uncontroversial move. There has been much discussion about these regulatory objectives and it is not the intention of this paper to revisit this. ${ }^{31}$ This paper considers two of the regulatory objectives, namely: the objectives of "protecting and promoting the consumer interest" and "protecting and promoting the public interest". As this paper will both argue, and demonstrate, attention appears to have been lavished on the former at the expense of the latter. This paper argues that rather than the LSB investing time and effort into understanding the public interest, the consumer interest has become the focus of most, if not all regulatory endeavours. The consumer interest has become firmly embedded in the lexicon of the LSB to the exclusion of any meaningful consideration of the public interest. This paper examines the approach of the LSB to the consumer interest and argues that there is evidence to suggest that the design of the regulatory structure and the process of regulatory decision making is such that regulation is being potentially captured by the consumer interest and those preoccupied with consumer affairs and consumerism. It demonstrates how this attention is stimulated by both the design of the LSA 2007 and, maybe, capture of the oversight regulator \& legal services regulation, not by the legal profession, as pre the Act it was commonly argued, but by the LSCP, the consumer lobby and the consumer interest. Moreover, this paper suggests that the LSB, and to a degree, the regulatory arms of the "Approved Regulators" have become "culturally captured." This reinforces, as argued elsewhere by this author, ${ }^{32}$ the point that there should be a more considered, evidence based approach towards the public interest at the forefront of every regulatory endeavour, before any consideration of the consumer interest. This paper discusses in the next section what is required to found a claim of regulatory capture. The second section analyses what the consumer

30 Laurel S Terry, Steve Mark and Tahlia Gordon, 'Adopting Regulatory Objectives for the Legal Profession’ (2012) 80 Fordham Law Review 2684.

31 Ibid.

32 Tim Sinnamon, 'The Public Interest and the Legal Services Act 2007' (PhD thesis, University of Surrey 2013). 
interest is, and establishes why pursuing it is not necessarily in the public interest. The third section identifies a number of structural features of the LSA 2007 which may, as a result of statutory creation, tilt regulation towards the consumer interest. These factors are important to any overall determination that capture of the legal services regulators has occurred. The fourth section reviews a number of decisions taken by the LSB. The final section draws together the points identified in the preceding sections and draws conclusions.

\section{REGULATORY CAPTURE AND THE CONSUMER INTEREST}

One of the intellectual arguments underpinning the developments that led to the LSA 2007 was that the legal profession had captured regulation for its own self-interest. ${ }^{33}$ Self-regulation by the professions was lambasted from a number of quarters. ${ }^{34} \mathrm{~A}$ number of commentators suggested that the regulatory environment at the time could be explained by private interest theories of regulation or capture. ${ }^{35}$ Many of these claims remain vulnerable to strict scrutiny especially as Stigler's ${ }^{36}$ rather arbitrary standard of causal inference, in connection with his private interest theories of regulation have been uncritically embraced by a subsequent generation of economists. ${ }^{37}$ This paper does not seek to unpack these claims - rather, it argues, that if anything there has been, if ever

${ }^{33}$ Richard Abel, English Lawyers Between the Market and State The Politics of Professionalism (OUP 2004); David Clementi, Review of the Regulatory Framework for Legal Services in England and Wales, Final Report (December 2004) 57-8; Robert Baldwin, Martin Cave and Kate Malleson, 'Regulating Legal Services: Time for the Big Bang?' (2004) 67 MLR 787; OECD, Competition in Professional Services (DAFFE/CLP 2000) 3-4; Iain Paterson and others, 'Regulation of Professional Services' (IHS, 2003)

$<$ http://ec.europa.eu/competition/sectors/professional_services/studies/prof_servi ces_ihs_part_1.pdf > accessed 22 July 2014.

${ }^{34}$ Ibid.

35 Frank Stephen, 'The Market Failure Justification for the Regulation of Professional Services Markets and the Characteristics of Consumers' in Claus Dieter Ehlerman and Isabela Atanasiu (eds) European Competition Law Annual 2004: The Relationship Between Competition Law and (Liberal) Professions (Hart Publishing 2004); Paterson (n 33).

${ }^{36}$ George Stigler, 'The Theory of Economic Regulation' (1971) 2 Bell Journal of Economics and Management Science 3.

${ }^{37}$ Daniel Carpenter and David A Moss, Preventing Regulatory Capture, Special Interest Influence and How to Limit it (Cambridge 2014) 8-9. 
there was capture by the professions, a pendulum swing, not necessarily to a neutral ground where regulation pursues policies free of capture, but, that matters have now swung beyond this, to a situation whereby regulation has become preoccupied with the consumer interest, as constructed and interpreted by the LSB, LSCP and lobbyists on behalf of discrete sections of the consumers of legal services. ${ }^{38}$

The argument that the LSB and regulators are now preoccupied by the consumer interest is not a particularly new one. A number of claims have been made to this end. ${ }^{39}$ Notably, Lord Neuberger has referred to "consumer fundamentalism" and the "tyranny of the consumer interest." 40 As recently as the 20 June 2014 he spoke of the dangers of the LSB regulating solely in favour of the consumer. ${ }^{41}$ This paper attempts to argue that rather than these being unjustifiable claims, as the previous Chairman of the $\mathrm{LSB}^{42}$ and current Chairwoman of the $\mathrm{LSCP}^{43}$ have tried to make

${ }^{38}$ The construction of the consumer interest by the LSB and LSCP has been by no means uniform or all embracing. It has concentrated on consumers of 'regular legal services' - (conveyancing, probate, small business matters etc) and vulnerable consumers (with specific impairments). It has not looked at the consumer in a wider sense - including the Government, the Courts, large businesses, society, the rule of law.

${ }^{39}$ Jonathan Goldsmith, 'The Core Values of the Legal Profession for Lawyers Today and Tomorrow' (2008) 28 North-Western Journal of International Law and Business 441; Ruth Deech, 'Regulating the Regulators' (Gresham College, 23 May 2012) <http://www.gresham.ac.uk/lectures-and-events/regulating-theregulators> accessed 27 July 2014.

${ }^{40}$ David Neuberger, 'The Tyranny of the Consumer or the Rule of Law' (Speech by Lord Neuberger Master of the Rolls $25^{\text {th }}$ Annual Bar Conference 6 November 2010); Neuberger D, 'Professional Discipline - Challenges for the Future' (Lord Neuberger, Master of the Rolls, Keynote Speech, Disciplinary Conference, 5 February 2010).

41 'Lord Neuberger at a Conference of the Bar Councils of Northern Ireland and Ireland, Belfast: The Future of the Bar' (The Supreme Court, 20 June 2014) $<$ http://www.supremecourt.uk/docs/speech-140620.pdf> accessed 14 August 2014; Dan Bindman, 'Neuberger Backs Single Regulator but Criticises LSB for Adding Cost and Confusion' (Legal Futures, 25 June 2014) $<$ http://www.legalfutures.co.uk/latest-news/neuberger-backs-single-regulatorcriticises-lsb-adding-cost-confusion> accessed 14 August 2014.

42 David Edmonds, 'Quality and Standards in a Liberalised Market' (Legal Services Board, 10 May 2012)

<http://www.legalservicesboard.org.uk/news_publications/speeches_presentation s/2012/20120510-david-edmonds-russell_cooke_speech.pdf> accessed 14 July 2014; Elizabeth Davies, 'Unreflective Consumer Fundamentalism: Who are the 
out - preoccupation with the consumer interest, to a point of regulatory capture, is an emerging reality. In addressing this claim it is important to set out firstly, the ingredients for a claim of consumer capture and secondly, the problems associated with the consumer interest which indicate that regulating primarily in this interest is neither pragmatic, appropriate, nor, necessarily in the public's interest.

\section{Regulatory Capture}

There were a number of early models and case studies developing the theory of regulatory capture and the general understanding of the attendant dangers. ${ }^{44}$ Beyond these early works there has been relatively little follow up in recent decades. ${ }^{45}$ In a traditional sense, critics maintain that regulatory capture stunts competition and innovation, as firms are able to capture their regulators effectively wielding the regulatory power of the state and can use it as a weapon to block the entry or success of other firms. ${ }^{46}$ Capture has thus been alleged - perhaps quite plausibly - to figure significantly in the major human and environmental crises of our

Unreflective Consumer Fundamentalists? (Legal Services Consumer Panel, 28 February 2013)

<http://www.legalservicesconsumerpanel.org.uk/how_can_we_help/blog/blog_en try_chair_march_2013.html> accessed 14 August 2014.

43 Elizabeth Davies, 'What is the Consumer Interest?: Using the Consumer Principles (Legal Services Consumer Panel, 20 November 2013) $<$ http://www.legalservicesconsumerpanel.org.uk/how_can_we_help/blog/blog_en try_chair_006_2013.html> accessed 14 August 2014.

${ }^{44}$ George Stigler, 'The Theory of Economic Regulation' (1971) 2 Bell Journal of Economics and Management Science 3. For a general account see: Robert Baldwin and Martin Cave, Understanding Regulation (Oxford 1999); Richard Posner, 'Theories of Economic Regulation' (1974) 5 The Bell Journal of Economics and Management Science 335; Kip Viscusi, John Vernon and Joseph Harrington, Economics of Regulation and Antitrust (2 ${ }^{\text {nd }}$ edn, MIT 1995); Peter Aranson, 'Theories of Economic Regulation: From Clarity to Confusion' (1990) 6 Journal of Law and Politics 247; Micheal Hankte-Domas, 'The Public Interest Theory of Regulation: Non-Existence or Misinterpretation?' (2003) 15 European Journal of Law and Economics 165, 185; Hans Maks and Niels Phillipsen, 'An Economic Analysis of the Regulation of Professions' in Lode Vereeck Regulation of Architects (Intersentia, 2002); Cass R Sunstein, After the Rights Revolution: Reconceiving the Regulatory State (University of Chicago Press 1990).

${ }^{45}$ Carpenter (n 37) 13.

${ }^{46}$ Ibid 1. 
time. ${ }^{47}$ Capture has also been blamed for severely under-cutting efforts at reform. ${ }^{48}$ Plugging some of the gaps in the scholarship is now an edited collection by Carpenter and Moss published in 2014. ${ }^{49}$ The text, which will surely become seminal, brings together a set of authors from a range of disciplines who attempt to gain a clearer grasp of what regulatory capture is, where and to what extent it occurs, what prevents it from occurring more fully and pervasively, and, finally, it attempts to distil lessons for policy makers and the public for how capture can be mitigated and the public interest protected. ${ }^{50}$ For present purposes, the text suggests a useful working definition of regulatory capture and the key ingredients against which a claim of capture should be judged.

"Regulatory capture is the result or process by which regulation, in law or application, is consistently or repeatedly directed away from the public interest and toward the interests of the regulated industry, by the intent and action of the industry itself." 51

Previous definitions and theoretical treatments of capture theory have focused on the regulated industry capturing the regulator for its own benefits. In the context of legal services this would be the legal profession capturing regulation for its own self-interest. These theories afford little room for the consideration of other interests capturing regulation. In a departure from existing theories, Carpenter ${ }^{52}$ notes that in principle, the word "industry" in their definition could be replaced with the word "interest" or "special interest." They advance this idea on the basis that they believe other actors have the potential to twist regulation to serve their own interests at the expense of the broader public interest. ${ }^{53}$ It is on the basis of this theoretical acknowledgement that this paper proceeds to argue that consumerism and the "consumer interest" in the hands of the LSB, LSCP and consumer lobby may be orientating regulation away from the public interest as a result of capture.

The foregoing definition of capture can be broken down into three distinct elements. Firstly, public interest; secondly, intent and thirdly, regulated industry. Carpenter and others also set out quite clearly the

\footnotetext{
47 Ibid 2.

48 Ibid 2.

49 Ibid.

${ }^{50}$ Ibid 2.

${ }^{51}$ Ibid 13.

52 Ibid 14.

53 Ibid 14.
} 
evidential burden required to establish a claim of capture. The Public Interest element is perhaps the most difficult element to qualify or quantify. Carpenter notes, as do a whole plethora of lawyers, political scientists and philosophers that both understanding and measuring the public interest is a "thorny problem as old as democracy". ${ }^{54}$ The author of this paper has also conducted significant research on this very problem in the context of legal services, ${ }^{55}$ noting that the LSB's own understanding of the public interest is problematical and lacking in many regards. ${ }^{56}$

The second element of Carpenter's definition requires intent. Carpenter argues that the fact that an industry or special interest is well served by regulation is deeply insufficient for a judgment of capture. Both intent and action on the part of the regulated industry or special interest are required. Unless the industry or special interest actively and knowingly pushes regulation away from the public interest, there can be no capture. Carpenter suggests the fact that an industry or special interest benefits from regulation, is, by itself, insufficient, because it could be alternatively explained by bureaucratic drift, coincidence, or mistakes, or a simple by product of public serving regulation. ${ }^{57}$

The third element of Carpenter's definition is consistent with many earlier theories of capture in which industry captures regulation for its own benefit. The industry or special interest needs therefore to derive some benefit from the regulation. Carpenter suggests that their definition of capture provides a set of standards for making statements about whether capture has occurred in the case of a given regulation or agency. He argues that three general empirical standards straightforwardly flow from their definition. To claim capture, they suggest an argument ought to provide a defeasible model of the public interest; show a policy shift away from the public interest and towards industry (special interest), and, show action and intent by the industry (special interest) in pursuit of this policy shift sufficiently effective to have plausibly caused an appreciable part of the shift. ${ }^{58}$

The extent of Carpenter and other's contribution to the literature is robust and there is much fruitful research to be conducted on a host of aspects of capture. Of particular note are the various ways in which, relatively subtly, scholars now suggest capture might come about. This is

\footnotetext{
${ }^{54}$ Ibid 13.

55 Tim Sinnamon, 'The Public Interest and the Legal Services Act 2007' (PhD thesis, University of Surrey 2013).

56 Ibid 172.

${ }^{57}$ Carpenter (n 37) 16-18.

58 Ibid.
} 
beyond the commonly understood methods of capture whereby political campaigns are funded by industry to exert influence, or, pressure is brought to bear on politicians, or the much discussed 'revolving door' method. ${ }^{59}$ In the context of legal services these more subtle forms of understanding how capture might occur are useful, as adducing evidence to substantiate a claim of capture in the traditional sense might prove difficult. Moving beyond the aforementioned crude incentives which might appeal to regulator's personal self-interest, James Kwak, ${ }^{60}$ Nolan McCarty $^{61}$ and Luigi Zingales ${ }^{62}$ each explore new mechanisms of understanding capture.

James Kwak investigates the idea of cultural capture. He has explored new ways by which regulators are influenced, even unknowingly, by interests through a combination of social, cultural and intellectual currents. ${ }^{63}$ Moving beyond other forms of capture - Kwak argues that "People's actions are the product of many different factors, and mixes of motivations are certainly possible." ${ }^{64}$ He argues that there is evidence to suggest that regulators act according to their ideological beliefs. ${ }^{65}$ This, he suggests, only raises the question of how those beliefs are formed and specifically how the administrative process exposes regulators in such a way that it can colour their beliefs. Both the capture model and the public interest model of regulatory action assume that regulators are rational actors: either they maximise their material self-interest or they maximise their consciously held policy interests. ${ }^{66}$ However, there is another possibility: that regulators are susceptible to non- rational forms of influence, which interest groups can exploit to achieve the practical equivalent of capture-favourable policy outcomes. Kwak describes three mechanisms by which a regulated industry, or special interest, is able to

\footnotetext{
${ }^{59}$ Ibid 18.

60 James Kwak, 'Cultural Capture and the Financial Crisis' in Daniel Carpenter and David A Moss (eds), Preventing Regulatory Capture, Special Interest Influence and How to Limit it (n 63).

61 Nolan McCarty, 'Complexity, Capacity, and Capture' in Daniel Carpenter and David A Moss (eds), Preventing Regulatory Capture, Special Interest Influence and How to Limit it (Cambridge 2014).

62 Luigi Zingales, 'Preventing Economists' Capture' in Daniel Carpenter and David A Moss (eds), Preventing Regulatory Capture, Special Interest Influence and How to Limit it (Cambridge 2014).

${ }^{63}$ Kwak (n 60).

64 Ibid.

65 Ibid.

${ }^{66}$ Ibid 71.
} 
shape regulators' beliefs and actions - mechanisms that should not work if regulators are rational beings not devoted to their self-interest or if they form their policy preferences rationally. They are:

Identity: Regulators are more likely to adopt positions advanced by people whom they perceive as being in their in-group.

Status: Regulators are more likely to adopt positions advanced by people whom they perceive to be of a higher status in social, economic, intellectual, or other terms.

Relationships: Regulators are more likely to adopt positions advanced by people who are in their social networks. ${ }^{67}$

The composition, background, experience, political affiliation of the many new actors involved in legal services regulation merits scrutiny and could form the basis of a study in and of itself. For present purposes, it is noteworthy that there is a flow of staff members between regulatory organisations in the city and in particular senior members from the former regulator Oftel to the LSB. There is also a flow to and from the LSB, Ofcom, the FCA, the Competition Authorities and others QUANGOS. ${ }^{68}$ From this it is plausible to suggest that there is an inter-exchange of ideas and methods of regulating - creating something of an "in group" and a broad based professional / social network. Existing studies have already identified this point in other sectors. ${ }^{69}$ It has also been identified that some

${ }^{67}$ Ibid 71.

68 As an example of this - David Edmonds (former Chair of the LSB), Chris Kenny Chief Executive of the LSB both previously worked at Oftel and David Edmonds remained for a while with Ofcom. Alex Roy, Research Director of the LSB has recently left to join the Financial Conduct Authority. Crispin Passmore, former LSB strategy Director is now the Executive Director of the Solicitors Regulation Authority.

${ }^{69}$ Peter Lunt and Sonia Livingstone, 'Regulation in the Public Interest' (2007) 17 Consumer Policy Review 4; Sonia Livingstone, Peter Lunt and Laura Miller, 'Citizens and Consumers: Discursive Debates During and After the Communications Act 2003' (University of Kent, October 2006) <http://www.kent.ac.uk/scarr/papers/Livingstone\%20Wk\%20Paper10.(2).pdf> accessed 22 July 2014; Sonia Livingstone, Peter Lunt and Laura Miller, 'Citizens, Consumers and the Citizen - Consumer: Articulating the Interests at Stake in Media and Communications Regulation' (2007) 1 Discourse and Communication 85, 97; Sonia Livingstone, 'What is the Citizen's Interest in Communication Regulation?: Ofcom's Agenda for "Citizens, Communications and Convergence”, (Conference Paper, LSE Research Online, 30 October 2008) 2 
of the "new regulators" 70 regulate in a similar way, using nearly identical "tools." These regulatory tools have also failed to get to grips with concepts analogous to the citizen or public interest. ${ }^{71}$

A casual review of the composition of the boards of the LSB, LSCP and SRA now reveals a membership of, on the whole, career board members often with past affiliations or current memberships of consumer organisations or competition promoting organisations. ${ }^{72}$ There is a loose similarity in the credentials, including academic and professional backgrounds, of many members of the various Boards which oversee the regulatory functions of the larger approved regulators. This again hints at many of the precepts of cultural capture outlined above. The similarity of the recent composition of the LSCP is something that has not escaped the attention of Baroness Ruth Deech who in a House of Lords Debate on referral fees noted:

"There is a perception that the Legal Services Board Consumer Panel may fail the test of impartiality and expert evidence. After a freedom of information request, it was revealed that the panel has an unbalanced political composition. Half of its members are declared members of the Labour Party and/or members of unionsthe unions being, of course, supporters of the Labour Party. Why does this matter? Because there is a conflict between the duty to represent the consumer and certain vested interests that are not always transparently declared in, for example, the Consumer Panel report on referral fees, which was adopted by the parent body, the Legal Services Board. The Labour Party itself is in receipt of referral fees. Lord Justice Jackson, in his Review of Civil Litigation Costs earlier this year, said that they should be banned in personal injury cases. So did the noble Lord, Lord Young of

(This work does not frame these observations in the context of capture or cultural capture).

70 'New regulators' is a term used commonly to describe a new breed of regulators brought about during the period of the Blair government. They were primarily concerned with economic regulation. They are variously lighter touch, public facing, risk centred, created by statute and funded by a levy on the industry they regulate and are usually accountable to parliament. See: Livingstone (n 69). ${ }^{71}$ Lunt (n 69).

72 John Kay, 'How to Spot a Good From a Bad Quango' (Financial Times, 12 October 2010) <http://www.ft.com/cms/s/0/cc7ff2e4-d651-11df-81f000144feabdc0.html\#axzz36FPyHHM4 > accessed 25 October 2014; notably Kay referred to a modern class of 'quangocrats' who glide effortlessly from committee to committee. 
Graffham, in his report on the claims culture. The Law Society has set its face against the practice. Therefore, it is odd that the LSB Consumer Panel has come out in favour of the retention of referral fees, whereby solicitors and others may buy in work by, for example, paying unions to refer business to them. Given that half of the Consumer Panel is made up of members of the Labour Party, the perception may be there-it is possible to make the criticism-that it could be influenced by the unwillingness of the party to give up a potential source of income from the firm of solicitors that acts on its behalf in personal injury cases."73

Returning to other ways in which capture may manifest itself, McCarty ${ }^{74}$ argues that the "provision of expertise by interest" - in which, as a result of heightened complexity, regulators come to rely on industry or interest groups expertise in ways that tilt decision making toward these particular interests. The very fact, as discussed later on in this paper that the LSB is duty bound to interact with the $\mathrm{LSCP}^{75}$ is a significant factor in any argument that a tilt has occurred in favour of the consumer interest. Moreover, the fact that the LSCP appears to repeatedly use certain research organisations, as does the LSB, shows a predisposition to particular ways of thinking.

Zingales $^{76}$ argues, that perhaps the most subtle of all methods of capture occurs by "economists capture" - in which industry or interest groups influences and incentivises scholars to favour a particular perspective in their work, thereby indirectly influencing regulators who rely on the scholars' judgment and expertise in making decisions. The next section identifies the fact that the LSB and others have been explicit in their commitment to market failure analysis and cost benefit analysis, commonly following the Treasury's Green Book methodology. ${ }^{77}$ These economic methodologies for decision making are also clearly to be found used in much of the research appropriated by the LSB despite market failure analysis coupled with cost benefit being roundly criticised. ${ }^{78}$ The

\footnotetext{
${ }^{73}$ Baroness Ruth Deech, HL Deb 9 November 2010, vol 722 col 170.

${ }^{74}$ McCarty (n 61).

${ }^{75}$ LSA 2007, ss 8-11.

${ }^{76}$ Zingales (n 60).

77 HM Treasury, The Green Book Appraisal and Evaluation in Central Government (HMSO 2003).

78 Christopher Decker and George Yarrow, Understanding the Economic Rationale for Legal Services Regulation (Legal Services Board, 2010) 12.
} 
following interrogates the concept of the consumer interest and discusses the way in which it has become the focus of economic methodologies.

\section{THE CONSUMER INTEREST}

The LSA 2007 in part helps in the search for an understanding of the consumer. Of all the terms that appear in the regulatory objectives, the only one that is further defined in the Act is "consumer". S 207(1) defines consumers as follows:

Legal Services Act 2007, s 207(1) ${ }^{79}$ “consumers” means persons

a) who use, have used or are, or may be contemplating using, services within (subsection 2) ${ }^{80}$

b) who have rights or interests which are derived from, or are otherwise attributable to, the use of such services by other persons, or

c) who have rights or interests which may be adversely affected by the use of such services by persons acting on their behalf or in a fiduciary capacity in relation to them

This definition is broadly constructed, however, adding "interest" 81 to it, to make "consumer interest," presents more of a definitional challenge. Prominent scholars in the world of consumer affairs have concluded that the term consumer interest "resists a single definition" and is "highly politicised". ${ }^{22}$ This is an experience borne out by many established regulators, who have made concerted efforts to understand what the

\footnotetext{
${ }^{79}$ LSA 2007, s 207(1).

${ }^{80}$ Ibid s 2(a): 'any services provided by a person who is an authorised person in relation to an activity which is a reserved legal activity, and, (b) any other services provided by a person which consist of or include a legal activity carried on by, or on behalf of, that person.'

${ }^{81}$ For the purposes of this paper, the term interest is not taken to be a sense of feeling or curiosity. Rather it relates to something being done, or enacted, or brought about, or maintained. It is a separate question from that of whether an individual must be aware of his interest. This approach broadly is an articulation of that commonly adopted in the literature pertaining to public interest scholarship. Virginia Held, The Public Interest and Individual Interests (Basic Books 1970) 18.

82 Stephen Broebeck, 'Defining the Consumer Interest: Challenges for Advocates’ (2006) 40 Journal of Consumer Affairs 177, 178.
} 
consumer interest is. ${ }^{83}$ Complex toolkits have been developed in the pursuit of diagnosing the consumer interest. ${ }^{84}$ Broebeck, has, however, noted that the consumer interest can be most usefully thought of in terms of "competition, representation, information and redress." 85 The Labour Government shed some light on its understanding of the consumer interest in the heated debates between itself and the House of Lords over proposed legislation, which later became the Communications Act 2003. ${ }^{86}$ To clarify the difference between the consumer and the citizen, borne out of a series of challenges to the language used in the Communications Bill presented to Parliament, the Government provided an explanatory memorandum. ${ }^{87}$ It noted that the consumer interest can be defined as the interest of a purchaser or other user of a good or service, normally based on an economic relationship between the individual and the supplier of the good or service in question. ${ }^{88}$ In comparison, the citizen interest may be defined as the interest of the individual in his or her capacity as a member of society and the public interest as the interest or good of society as a whole. ${ }^{89}$ In connection with the consumer interest, this has led scholars to note: "in a general sense one can define consumer interests in the market as related to four market characteristics of price, service, quality and choice." $" 90$

83 Ofcom, 'Capturing the Consumer Interest: A Report of the Launch of the Toolkit for Regulators and Government' (Ofcom, 2 February 2006) $<$ http://www.communicationsconsumerpanel.org.uk/downloads/Policy/Consumer \%20InterestToolkit/Events/Capturing\%20the\%20Consumer\%20Interest\%20A\%2 0report\%20of\%20the\%20Launch\%20etc.pdf > accessed 22 July 2014.

84 LSCP, 'The Consumer Interest - Using Consumer Principles Consumer Toolkit' (LSCP, January 2014)

$<$ http://www.legalservicesconsumerpanel.org.uk/ourwork/ConsumerEngagement/ documents/UsingConsumerPrinciples2014.pdf> accessed 18 August 2014.

85 Broebeck (n 82).

${ }^{86}$ Communications Act 2003.

87 DTI/DCMS, 'Note by the Department of Trade and Industry and the Department for Culture. Media and Sport on the Meaning of "Customer", "Consumer" and "Citizen"' (Parliament, June 2002) <http://www.parliament.thestationery-office.co.uk/pa/jt200102/jtselect/jtcom/169/2070808.htm> accessed 22 July 2014.

88 Ibid.

89 Ibid.

90 Eugène Buttigietg, Competition Law: Safeguarding the Consumer Interest - A Comparative Analysis of US Antitrust Law and EC Competition Law (Wolters Kluwer 2009) 1. 
This characterisation of the consumer, therefore, moves beyond a more general understanding of the consumer interest in terms of consumer rights and consumer protection. It reflects a more enhanced understanding of the consumer, as an individual with preferences and as a prime feature of the market. The Government's focus on the consumer in the Legal Services Bill followed the trend embodied in its other public sector reforms. This leads therefore to an argument and hypothesis that "protecting and promoting the consumer interest" was concerned with ensuring the market mechanism worked effectively. ${ }^{91}$

The market perspective of the consumer interest is arguably of critical importance, as in a number of situations the market may not be compatible with other socially desirable outcomes. ${ }^{92}$ Market failure is commonly used as the intellectual premise upon which many regulators approach regulation. ${ }^{93}$ It therefore provides a valuable lens with which to further view the consumer interest. The use of market failure is clearly apparent among many of the regulators created since 1997. The FSA ${ }^{94}$ and the LSB ${ }^{95}$ explicitly note that they use this approach in the process of decision making regarding policy and regulation. There is evidence that

${ }^{91}$ There is clear evidence of this assertion in the following speeches by senior members of the Legal Services Board. Chris Kenny, 'Alternative Business Structures and the Legal Services Market - Impact one Year on and Future Challenges' (Speech at the Westminster Legal Policy Forum, 18 October 2012); David Edmonds, 'Quality and Standards in a Liberalised Market' (Address by the Chairman of the Legal Services Board, Russell Cooke Forum, 10 May 2012).

${ }^{92}$ For an outline account see Stephen Mayson, Legal Services Regulation and "The Public Interest" (Legal Services Institute 2011); for a more developed account: Mike Feintuck, The Public Interest in Regulation (OUP 2004); Barry Bozeman, Public Values and Public Interest (Georgetown University Press 2007); Deborah Satz, Why Some Things Should Not be for Sale: The Moral Limits of Markets (OUP 2010).

${ }^{93}$ Harry McVea 'Financial Services Regulation under The Financial Services Authority: A Reassertion of the Market Failure Thesis' (2005) 64 CLJ 413.

94 'Effective Inspection and Enforcement: Implementing the Hampton Vision in the Financial Services Authority' (National Audit Office, 2008) $<$ http://www.nao.org.uk/publications/0708/hampton_financial_services_au.aspx> accessed 22 July 2014; McVea (n 93).

95 Alex Roy, 'Understanding the Economic Rationale for Legal Services Regulation' (Legal Services Board, 2011)

$<$ http://www.legalservicesboard.org.uk/news_publications/latest_news/pdf/econo mics_of_legal_services_regulation_discussion_papers_publication_final.pdf $>$ accessed 22 July 2014. 
other regulators, including Ofcom ${ }^{96}$ commonly use this method, though they do not appear to have explicitly stated so, in the same way as the FSA and the LSB. ${ }^{97}$ The Government's Green Book ${ }^{98}$ also mandates market failure analysis and cost benefit analysis as the principal rationale for government intervention regarding the operation of markets and institutions. ${ }^{99}$ The following outlines the theory, and then considers it as a tool for policy and decision making.

The market failure theory is a consumer orientated theory of regulation, ${ }^{100}$ rooted in the idea that market forces are the best means of ensuring that consumers' needs are met. Underlying the theory is the assumption that consumer preferences are more likely to be satisfied when firms engage in fierce and constant competition with each other. In the situation of a perfect market, ${ }^{101}$ the market is said to generate benefits for consumers in terms of price, innovation, quality, and variety of service (choice). These outcomes are only true under conditions of perfect competition. ${ }^{102}$ Given that markets are seldom perfect and suffer from a variety of deficiencies, regulation is justified when it aims to eliminate market failures and so restore a competitive equilibrium. The justifications for regulation under the market failure thesis are limited to instances of information asymmetries; externalities; anti-competitive practices and public goods. ${ }^{103}$ The economic justification for the market failure approach is that through market based transactions enshrined in the idea of mutually beneficial, voluntary exchanges - consumer preferences are best satisfied and scarce resources are shifted to where they are most valued on the basis of willingness to pay otherwise known as "allocative

\footnotetext{
96 For an overall account of the market failure approach taken by Ofcom see: Tony Prosser, 'Regulation and Social Solidarity' (2006) 33 Journal of Law and Society 364, $367-369$

${ }^{97}$ Roy (n 95).

${ }^{98}$ HM Treasury (n 77).

${ }^{99}$ Ibid.

${ }^{100}$ McVea (n 93).

101 Ibid.

102 Perfect competition presupposes: clearly defined property rights, non- natural monopolies; no barriers to entry; no transaction costs.

103 Frank Stephen, 'The Market Failure Justification for the Regulation of Professional Services Markets and the Characteristics of Consumers' in Claus Dieter Ehlerman and Isabela Atanasiu (eds), European Competition Law Annual 2004: The Relationship Between Competition Law and (Liberal) Professions (Hart Publishing 2004).
} 
efficiency." ${ }^{104}$ Market failure establishes, however, only a prima facie case for regulation, and in some instances the costs of regulation may outweigh any benefits. Market failure analysis is therefore often accompanied by a cost-benefit analysis. ${ }^{105}$ The consumer interest is, through this approach, essentially a by-product of the process of the market operating properly. The market, free of regulation, yields benefits in the consumer's interest in terms of lower prices, more innovative services, better choice of services and better quality. However, within what is a relatively simple hypothesis, the consumer is construed narrowly. The following outlines some broad problems associated with the approach.

The market failure theory is, by definition, rooted in the theory of private value and is driven by a concern for pricing efficiency. ${ }^{106}$ The narrowness of the approach has led to a number of studies which have shown that market failure negates broader public values, beyond the economic, and especially outcomes where the technical efficiency of prices is not a primary consideration. ${ }^{107}$ Bozeman $^{108}$ notes that the pervasiveness of market failure reasoning ensures a built in conservatism in public policy which often results in the neglect of public values. This is because the model marginalises many collective values by simply not dealing with them. This raises an important point. The market, by definition, is concerned with individual values; it is not concerned with collective values which may be important to the whole of society. This is significant in matters to do with the law, the environment and culture. In regards to law, concepts such as the rule of law, access and administration of justice, honesty and dignity, duties to the court, reputation, sustainability, independence and ethics are not easily translated into values that can be expressed in monetary terms. The market failure model and the consumer are therefore just concerned with the market. It is not

\footnotetext{
104 Ibid.

105 HM Treasury (n 77) 52; McVea (n 93) 413.

106 Barry Bozeman, Public Values and Public Interest (Georgetown University Press 2007) 5.

107 Richard Zerbe and Howard McCurdy 'The Failure of Market Failure' (1999) 18 Journal of Policy Analysis and Management 558 - The comprehensive critique analyses Lighthouses, Land Tenancy, Bees and Crops, Common Property, concluding that in each of these cases the theoretical proposition put forward by Market Failure when tested empirically was incorrect. The authors suggest that the correct normative theory rests on transaction costs, which is inherently based on significant empirical enquiry.

108 Bozeman (n 106) 20.
} 
concerned with other factors which may be of importance. Market failure, is, as Sagoff argues, a perfectly appropriate measure of the consumer's interest. ${ }^{109}$ Interests can accurately be assessed in terms of price, which reveals what individuals are willing to pay to obtain what they want. ${ }^{110} \mathrm{He}$ posits that the model deals with the efficiency of markets and how one knows that markets are not efficient. It is not, he asserts, about people and social institutions. ${ }^{111}$

Despite these problems, market failure is widely used by policy makers and regulators. Decker and Yarrow have commented on the unreflective use of market failure analysis and concluded that analysts tend to jump straight from a finding of "market failure" to a conclusion that intervention is not just potentially warranted, rather, they omit further investigation and assert that intervention is actually warranted. ${ }^{112}$ Beyond this, there are a number of more subtle problems with the way in which the model constructs the preferences the market seeks to promote. The following sets these out.

The traditional view of the free market is a presumption that what justifies regulation is market failure, or more specifically, the failure of the market by itself to achieve efficiency. ${ }^{113}$ The purpose of regulation under this model is to restore the market to its natural condition, or as close an approximation of that condition as can be hoped for. ${ }^{114}$ Efficiency in this context has been explained by Posner as follows: "Efficiency is a technical term: it means exploiting economic resources in such a way that human satisfaction as measured by aggregate consumer willingness to pay for goods and services is maximised." ${ }^{115}$ Whilst, as noted, this approach is good at understanding the consumer's interest, a number of scholars have queried whether the consumer interest is worth satisfying. Notably, Sagoff has argued: "an efficiency criterion assumes that the goals of our society are contained in the preferences individuals reveal or would reveal in

109 Mark Sagoff, 'Economic Theory and Environmental Law' (1981) 79 Michigan Law Review 1393.

110 Ibid.

111 Peter Brown, 'The Failure of Market Failures' (1992) 21 Journal of Socio Economics 1, 1-24; Brown argues that it is premised on shallow utilitarianism and as such is a prisoner to its foundations in economic individualism.

112 Decker (n 78) 12.

113 Edward Rubin, 'Deregulation, Reregulation, and the Myth of the Market' (1988) 45 Washington and Lee Law Review 1249, 1258.

114 Ibid.

115 Posner (n 44). 
markets." ${ }^{116}$ These individual preferences are not fixed, ${ }^{117}$ are subjective $^{118}$ and reflect a number of cultural and maybe societal conditions. ${ }^{119}$ Further to this, these individual preferences are capable of changing. Were they not, there would be no place in the world for advertising, salespeople and consumer psychologists. The theory works on the premise that autonomously created, materially defined self-interests do exist, and it is the collective expression of these interests through market purchases which leads to optimal resource allocation. ${ }^{120} \mathrm{~A}$ critical argument flows from this that a preference satisfying policy will only be as good as the preferences as understood, and there is nothing that guarantees that the preferences will be the right ones, or ones worth having. ${ }^{121}$ Many examples abound to explain this point. Sagoff, frames the key issue as follows:

"As consumers, indeed, we buy the least expensive goods, and in that way reveal a preference for lower worker safety standards, since they bring lower prices with them. Yet as citizens we may regard ourselves as Americans together and therefore responsible for the decency of workplace conditions. Likewise many of us who never visit a magnificent landscape may believe nevertheless that society has a duty to preserve it. Concerns such as these impersonal values rather than consumer preferences may become more important to us than our personal or economic interest." ${ }^{122}$

In the context of legal services, Stempel makes a similar point but builds on it by noting the importance of considering collective values in addition to individual consumer values in the context of the law.

\footnotetext{
${ }^{116}$ Mark Sagoff, 'At the shrine of Our Lady of Fatima or Why Political Questions are Not All Economic’ (1981) 23 ACJ 1283.

117 Jane Barron and Jeffrey Dunoff 'Against Market Rationality: Moral Critiques of Economic Analysis in Legal Theory’ (1996) 17 Cardozo LR 431; Mark Sagoff 'On Preserving the Natural Environment (1974) 84 Yale LJ 205, 207.

118 Stephen Broebeck, 'Defining the Consumer Interest: Challenges for Advocates’ (2006) 40 Journal of Consumer Affairs 177, 178.

${ }^{119}$ Rubin (n 113) 1267.

${ }^{120}$ McVea (n 93) 441.

${ }^{121}$ Mark Sagoff, 'The Principles of Federal Pollution Control' (1986) 71 Minn L Rev 19, 58.

122 Mark Sagoff, 'Values and Preferences’ (1986) 96 Ethics 301, 311.
} 
"As a consumer, I am a participant in markets. My aim is to enhance my own well-being, by satisfying my preferences, which I express through market behaviour. As a citizen, my concern is different. It is a concern not with what is best for me but with what is right for us. My aim is to participate in deliberation with my fellows, and I consider not only my preferences but my (and our) values as well. Frequently, my consumer preferences coincide with the values I support as a citizen; sometimes, however, they do not. Because our aims as consumers and citizens are somewhat schizophrenic, public and private life both require a never-ending negotiation between consumer values and citizen values.” ${ }^{123}$

The focus on consumer preferences alone is not desirable. McVea ${ }^{124}$ argues that consumer preferences "tells us nothing about, indeed, it seems unconcerned with whether -those preferences are worth having." ${ }^{125}$ This is not an isolated assertion. Sagoff suggests that it cannot be argued that the satisfaction of preferences is a good thing in itself for many preferences are sadistic, envious, racist or unjust. ${ }^{126}$ Furthermore, in the context of preferences, McVea has noted that markets also pander to particular types of preferences (more is better than enough) and tend to systematically favour the lowest common-denominator amongst the spectrum of consumer preferences. ${ }^{127}$ What emerges from the foregoing is that one of the main methods of regulators decision making is largely predicated on both a narrow conception of the consumer interest, and secondly, is compromised in considering collective interests that may affect society as a whole. The market model is concerned with the market. There is little in the model which can discern when the consumer interest is compatible with the public interest, or when it is not. The market model pursues the market vision, irrespective of whether this is in the collective public interest or not. This raises a number of questions as to whether this is an appropriate method of approaching the regulation of legal services.

123 Jeffrey Stempel, 'Embracing Descent: The Bankruptcy of a Business Paradigm for Conceptualising and Regulating the Legal Profession’ (1999) 27 Florida State University Law Review 120.

${ }^{124}$ McVea (n 93).

125 Jane Barron and Jeffrey Dunoff, ‘Against Market Rationality: Moral Critiques of Economic Analysis in Legal Theory’ (1996) 17 Cardozo LR 431; Sagoff (n 117); McVea (n 93); Sagoff (n 122)

${ }^{126}$ Sagoff (n 121).

${ }^{127}$ McVea (n 93). 


\section{STRUCTURAL POSITIONING OF THE CONSUMER INTEREST}

Understanding the problems with the consumer interest and the way in which it is commonly located within decision making processes is important in any overall determination of consumer capture, as it locates the objection towards regulators regulating in its interest without thoughtful consideration of the public interest. This section considers some factors which, in part, may explain the emphasis accorded to the consumer interest by the LSB. The following outlines the socio-political and economic influences which led to the emphasis afforded to the consumer interest in the LSA 2007. The following argues that the LSA 2007 is both stylistically and substantively a piece of economic regulation - drafted in a style that presents a number of interesting and, as yet, unresolved questions. It argues that the method of regulation, characteristic of the early years of the millennium, spawning a number of QUANGO regulators, has, through a form of "Group Sync" and New Public Management ${ }^{128}$ influences, come to regulate in the consumer interest because it is amenable to relatively simplistic quantification and apparently transparent regulation. Whilst the Legal Services Bill was drafted with a strong economic and consumer emphasis, absent any reference to the public interest - this paper reiterates the fact that the overriding purpose of regulation is to further the public interest. Whilst this is a simple matter of understanding for most, the explanatory notes to the LSA 2007 are Delphic and vague. Without promoting a clear hierarchy of regulatory objectives with the public interest at the top, it is perhaps understandable, but unforgivable, that regulators have sought to prioritise the consumer interest. The following section also draws attention to the statutory creation of the LSCP and its very close relationship with the LSB. This section challenges this narrowly constructed formalised champion of the consumer interest within the LSB whilst noting that no other interest group is accorded such a privilege. The final argument made is that there is a long-standing recognition that charging a regulator with being a champion of both the consumer interest and the public interest is a problematical combination which might come to have serious consequences.

128 'New Public Management'. This prioritises the efficiency of public sector administration rather than an orientation towards broader values which many regard as important. Consequently, a burgeoning area of study is to be found attempting to reconnect public services and management to public values; Bozeman (n 106). 
There has been a long pedigree of claims, extending over 40 years, that the legal profession and legal services market should be liberalised. ${ }^{129}$ Many accounts set out the background to these claims. ${ }^{130}$ It was only in and around the early years of the Millennium that a number of catalysts coalesced to provide the requisite political will and potential for achieving a successful outcome for a piece of far reaching legislation reforming legal services. The Labour Government's appetite for reforming the legal professions was perhaps most advantaged, politically, by a highly publicised problem with the handling of complaints made against Solicitors. ${ }^{131}$ This problem fuelled a co-ordinated and sustained campaign

${ }^{129}$ MMC, A Report on the General Effect on the Public Interest of Certain Restrictive Practices (HMSO 1970); OECD, Competition in Professional Services (DAFFE/CLP 2000); Royal Commission on Legal Services, The Royal Commission on Legal Services in England and Wales: Final Report (HMSO 1979); Robin White, A Guide to the Courts and Legal Services Act, 1990 (Fourmat Publishing 1991); Richard Abel, English Lawyers Between Market and State (OUP 2004); Great Britain, The Work and Organisation of the Legal Profession (Stationary Office Books 1989); Great Britain, Conveyancing by Authorised Practitioners (Stationery Office Books 1989); Great Britain, Contingency Fees (HMSO 1989); Michael Zander, 'The Thatcher Government's Onslaught on the Lawyers: Who Won?' (1990) 24 International Law 753, 759; Laurel S Terry, 'The European Commission Project Regarding Competition in Professional Services' (2009) 29 Northwestern Journal of International Law and Business1, 1-10; Iain Paterson and others, 'Economic Impact of Regulation in the Field of Liberal Professions in Different Member States: Regulation of Professional Services' (IHS,2003)

$<$ http://ec.europa.eu/competition/sectors/professional_services/studies/prof_servi ces_ihs_part_1.pdf> accessed 11 July 2014; DCA, Competition and Regulation in the Legal Services Marketplace (CP(R2) 2003) 20; Michael Zander, Lawyers and the Public Interest (Weidenfeld Nicolson 1968).

${ }^{130}$ Richard Abel, English Lawyers between Market and State (OUP 2004); Judith L Maute, 'Revolutionary Changes to the English Legal Profession or Much Ado About Nothing?' (2006) 17 Professional Lawyer 1, 7; Mary Seneviratne, 'Consumer Complaint and the Legal Profession: Making Self Regulation Work?' (2000) 7 International Journal of the Legal Profession 39; Mary Seneviratne, The Legal Profession: Regulation and the Consumer (Sweet and Maxwell 1999) ch 5; Mark Davies, 'The Regulatory Crisis in the Solicitors Profession' (2003) 6 Legal Ethics 2; Robert Baldwin and others, 'Regulating Legal Services: Time for the Big Bang' (2004) 67 MLR 787.

131 Richard Moorhead, 'Self-Regulation and the Market for Legal Services' (Cardiff Working Papers, 2004) <http://www.ccels.cf.ac.uk/archives/publications/2004/moorheadpaper.pdf> accessed 19 August 2014; Mary Seneviratne, 'Consumer Complaint and the 
by a number of consumer organisations - who for a long time had been challenging the perceived monopoly of the legal profession. The OFT's interest in reform, buoyed by a number of developments in the EU and at the OECD also meant that the time was ripe for change. ${ }^{132}$ What has been overlooked by many commentators was the fact that the Legal Services Bill was introduced to Parliament at a time where the Labour Government was preoccupied with pursuing a neo-liberal, consumer friendly inspired deregulation agenda. ${ }^{133}$ The result being that the Legal Services Bill was drafted along strictly economic lines. ${ }^{134}$ That is to say it was a piece of economic regulation in all but name. This in part explains the insertion of regulatory objectives - which are a drafting feature of regulation, and primarily economic regulation at that time. In essence, the consumer lobby and Government were simultaneously pursuing an outcome which sought to improve the lot of the consumer through market means. To illustrate this point, the public interest, which had until 2002 appeared as a term in many of the documents evaluating the legal professions, was given

Legal Profession: Making Self Regulation Work?' (2000) 7 International Journal of the Legal Profession 39.

132 OFT, Competition in Professions (OFT 328, 2001); OFT, Competition in Professions - Progress Statement (OFT 385, 2002)

133 Stephen Broebeck, 'Defining the Consumer Interest: Challenges for Advocates' (2006) 40 Journal of Consumer Affairs 177, 178; Michelle Everson, 'Legal Construction of the Consumer' in Frank Trentmann (ed), The Making of the Consumer: Knowledge, Power and Identity in the Modern World

(BERG 2005); John Clarke, Janet Newman and Louise Westmarland, 'Creating Citizen-Consumers? Public Service Reform and (un)Willing Selves' in Sabine Maasen and Barbara Sutter (eds), On Willing Selves: Neoliberal Politics and the Challenge of Neuroscience (Palgrave Macmillan 2007) 125-145; Thomas Frank, One Market Under God: Extreme Capitalism, Market Populism and the End of Economic Democracy (Anchor Books 2001) 25; Wendy Larner, 'Neo-Liberalism: Policy, Ideology, Governmentality’ (2000) 63 Studies in Political Economy 5.

134 The Select Committee on Regulators, UK Economic Regulators (HL 20062007, 189-I; The Select Committee on Regulators, UK Economic Regulators (HL 2006-2007, 189-II) The report focuses on economic regulators. Whilst the LSA 2007did not necessarily set out to create a specific economic regulator, the Legal Services Board has clearly acknowledged that it views a rather substantial part of its statutory remit as creating this responsibility. 'If we're not an economic regulator, why on earth did Parliament write in all the stuff in the Act about bringing in alternative business structures? What is that, if not breaking down barriers to entry in a form of economic regulation?'; Legal Futures 'Edmonds Comes Out Fighting' (Legal Futures, 27 April 2012) $<$ http://www.legalfutures.co.uk/latest-news/edmonds-comes-out-fighting-indefence-of-lsb> accessed 23 July 2014. 
scant consideration after Lord Chancellor Irving left office. The term public interest did not feature in any of the documents, reports or consultations in the period 2002- 2007.

As a result of the successful passage of the LSA 2007 this brought about a number of regulatory innovations which, in one way or another, can be seen in other pieces of regulation. Similar to the LSA 2007 the Communications Act 2003 gave birth to a QUANGO oversight regulator. Studies reveal that there is a degree of similarity of approach in the ways in which these regulators regulate. ${ }^{135}$ In particular they hold themselves out to be evidenced based regulators. However, the approaches taken towards evidence and transparent regulation have yielded some interesting results. The Hampton ${ }^{136}$ requirement for transparent decision making has, in line with the neo liberal inspired "New Public Management" approach sought methods by which regulatory decisions can be defended. As mentioned earlier in this paper - market failure coupled with cost benefit analysis is these regulators stock in trade. Naturally this means that consumer interested policies are prioritised because these simplistic economic tools provide a methodology by which regulators can defend their decisions. Moreover, it provides a panacea by which ideologies of the regulators may be aired. ${ }^{137}$ Studies reveal that other regulators have been unable, unwilling or incapable of making, or taking, decisions

135 Lunt (n 69).

136 The following five principles were identified by the Better Regulation Task Force in 1997 - otherwise known as the Hampton Principles. Regulatory activities should be transparent, accountable, proportionate, consistent and targeted only at cases in which action is needed. These principles are inserted specifically in the Act at LSA 2007, pt 2, s 3(a).

137 As an example - See David Edmonds: 'We have a very simple goal - to reform and modernise the legal services marketplace in the interests of consumers, enhancing quality, ensuring value for money and improving access to justice across England and Wales'; Legal Services Board, 'Strategic Plan 201215 Business Plan 2012/13’ (LSB, April 2012)

<http://www.legalservicesboard.org.uk/news_publications/publications/pdf/busin ess_plan_201213_final.pdf> accessed 30 April 2014, 11; David Edmonds: 'We want regulators to step back from dictating the services offered and the structures of businesses operating in the legal services market to allow market forces to play a greater role. This we believe will help create a legal services market that is the right size for consumers.' David Edmonds, 'Regulatory Standards and assessing regulatory performance’ (Legal Compliance Bulletin, 2012)

<http://www.legalservicesboard.org.uk/news_publications/speeches_presentation s/2012/legal_compliance_bulletin_article_issue_20_july_2012.pdf > accessed 30 April 2014. 
orientated by the public interest or the citizen interest - for reasons to do with both the method of regulating and ideological predispositions. ${ }^{138}$

The draft Legal Services Bill appeared without a regulatory objective to protect and promote the public interest. This was rectified in the House of Lords after significant debate. In some regards the debates in the House of Lords might well have ameliorated some of the effects of capture by the consumer lobby. The background to the LSA 2007 set its sights ideologically on promoting the consumer. This was synonymous with the Labour Government's policy disposition at the time. Therefore, from the start, the legislation has been orientated towards the consumer. This emphasis has, in a way proved rather difficult to rationalise when it comes to understanding the regulatory objectives. The explanatory notes to the Act provide that the regulatory objectives are not ranked in terms of any importance. This is something that the LSB has been keen to point out. However, for anyone acquainted with regulatory theory - regulation should promote and protect the public interest. Any argument to the alternative is wholly misguided. However, as has been noted in this paper, the public interest is an amorphous concept and apt to be manipulated in a way which can give rise to outcomes which are not in the public interest. In a sense, when it comes to the interpretation of the regulatory objectives - the public interest is easily subordinated or subverted. To understand the public interest requires much consideration from a regulator with ideological neutrality. David Edmonds and Chris Kenny of the LSB have never recanted in their frequent speeches and presentations from eulogising about the wisdom of free market economics, the capacity of markets to operate largely free of regulation and finally the benefits of protecting consumers and consumerism. Therefore, whilst it is clear that the ideological disposition of the LSB has pursued these ideas - it is in part, the drafting of the LSA 2007 that might be challenged for not more robustly framing the public interest as the principle purpose of regulation.

The LSB's own interpretation of the public interest which equates it with "public confidence" bears testament to the ease with which the regulator has been able to decide, largely unchallenged, what the public interest is. ${ }^{139}$ As has been rightly identified - even if "public confidence"

138 Lord Currie, Chair of Ofcom, was so incensed that he is on record as saying that the wording of the Communications Act confused the clear vision of Ofcom as an economic regulator See: Lord Currie, (English National Forum Seminar Speech, 7 July 2003) <http://media.ofcom.org.uk/2003/07/07/english-nationalforum-seminar/> accessed 12 August 2014.

139 Legal Services Board, Business Plan 2010-2011 (LSB, 2010). <http://www.legalservicesboard.org.uk/news_publications/publications/pdf/final_ 
were an appropriate encapsulation of the public interest, which it is not, the absence of a caveat that it must be "justifiable public confidence" leaves much to be desired. ${ }^{140}$ In short, structurally, in an assessment of capture of regulation - the LSA 2007 provides the conditions through which emphasis may be accorded to other regulatory objectives as opposed to the public interest.

Evidence of potential consumer capture by those advocating the consumer interest in the period leading to the LSA 2007 is again apparent in the text of the Act. Whereas the previous paragraph might be explained as emphasis being accorded to the consumer interest as a result of omission - that is to say insufficient attention was given to framing the public interest as the objective to which all other objectives must be subordinated - this section deals with a matter of commission. Part 2 Section 8 LSA 2007 requires the LSB to establish a Legal Services Consumer Panel to represent the interest of consumers. ${ }^{141}$ The LSCP may make such arrangements as it thinks fit for committees established by the panel to give advice to the panel about matters. ${ }^{142}$ The LSCP makes its own arrangements for procedures, committee structures and decision making. The LSB must consider any representation made to it by the LSCP. ${ }^{143}$ If the LSB disagrees with the LSCP on a view expressed or a proposal made, in the representations, it must give the LSCP a notice to that effect stating reasons for disagreeing ${ }^{144}$ The LSCP may publish such information as it thinks fit about any representation made by the LSB. In essence the LSCP can say what it wishes and it has a right to publicly disagree with the LSB - even after the LSB has set out its reasons for disagreeing. The function of the LSCP is "to carry out research for the Board' and 'give advice to the Board." The LSB is mandated to consider any advice given and the results of any research carried out under this section. ${ }^{145}$ The LSCP website notes:

"We are located inside the Legal Services Board which allows us to put across the consumer view from the beginning to the end of

annual_plan_2010.pdf> accessed 15 August 2012 (this document sets out the LSB's interpretation of the regulatory objectives).

${ }^{140}$ David Neuberger, 'Professional Discipline - Challenges for the Future' (Keynote Speech, Disciplinary Conference, 5 February 2010).

${ }^{141}$ LSA 2007, pt 2, s 8.

${ }^{142}$ LSA 2007, pt 2, s 9.

${ }^{143}$ LSA 2007, pt 2, s 10(1).

${ }^{144}$ LSA 2007, pt 2, s $10(2)$.

${ }^{145}$ LSA 2007, pt 2, s 11(2). 
the policy-making process. However, the Consumer Panel is fully independent of the Board - we commission and carry out independent research, advise the LSB on the interests of consumers, and scrutinise the LSB's work on behalf of consumers." 146

The intricate details of how the LSB and LSCP interact and how the latter is funded are set out in a Memorandum of Understanding signed in 2010. The point to be taken from the mere existence of the LSCP - is that no other interest group is represented so completely and closely at the heart of the oversight regulator and legal services regulation. No public interest panel, rule of law panel or professional lawyering panel exists. Suggestions were made that there should be a panel to represent the legal profession during the debates on the Legal Services Bill in the House of Lords - but this was roundly rejected. ${ }^{147}$ The extent to which there is a sharing of information and approach by the LSCP and LSB - in partexplains some of the arguments posited below. For present purposes, however, the structure of the legislation and the direct representation of the consumer at the heart of legal services regulation links to another point, first raised by Ben Lewis in the 1930's concerning research undertaken into the National Recovery Board in America, an initiative created during the first New Deal project. ${ }^{148} \mathrm{He}$ drew attention to the following critical point:

"to place any official in the position of having to represent both the public interest and the consumer interest is to make him both the judge of all parties and counsel for one of the parties at interest." 149

${ }^{146}$ LSB and LSCP, 'Memorandum of Understanding Between LSB and LSCP' (LSB, 14 January 2010)

$<$ http://www.legalservicesconsumerpanel.org.uk/publications/corporate_documen ts/documents/MOU_LSB_CONSUMERPANEL.pdf> accessed 10 August 2014.

${ }^{147}$ Lord Kingsland HL Deb 15 May 2007 vol 692 pt 86.

148 The 1997 Labour Government used the ideological label 'New Deal', based loosely on the ideas that underpinned the first 'New Deal'.

${ }^{149}$ Ben Lewis, 'The "Consumer" and "Public" Interests under Public Regulation' (1938) 46 Journal of Political Economy 97, 100. 
It is perhaps no coincidence that after the failure of the financial system in $2007,{ }^{150}$ there was a scramble to re-organise the architecture of the Financial Services Authority, which had previously been responsible for a whole host of matters, including prudential regulation of the financial services industry in the wider public interest and consumer protection in the consumers' interest. ${ }^{151}$ The Financial Services Act $2010,{ }^{152}$ comprehensively split these functions up to include the Prudential Regulatory Authority (concentrating on economic and financial stability), the Economic Crime Agency and the Financial Conduct Authority (concentrating on the conduct of business regulation). The latter now has a much less consumer orientated role than originally undertaken by the Financial Services Authority. ${ }^{153}$

The foregoing has sought to explain that there are a number of factors built into the fabric of the LSA 2007 which might explain why the product of regulation is now orientated towards the consumer interest. On this basis alone there remains an interesting avenue of work to assess the extent to which the LSA 2007 was itself the subject of capture by those with a consumer interest. The following moves away from considering these inherent features of the LSA 2007 to consider how the LSB has approached 3 instances of regulatory decision making.

\section{CONSUMER CAPTURE -REFERRAL FEES, LAY CHAIRS AND THE LETR}

Referral fees involve payments by lawyers to organisations who are in a position to secure potential clients eg estate agents, insurance companies and trade unions. The subject of referral fees has been very

${ }^{150}$ Evan Turgeon, 'Boom and Bust for Whom? The Economic Philosophy behind the 2008 Financial Crisis' (2009) 4 Virginia Law and Business Review 1.

${ }^{151}$ Financial Services Act 2010.

152 Ibid.

153 This was previously going to be named the Consumer Protection and Markets Authority. Attention has been focused on the change of name in the following paper: - James Perry et al, 'The new UK regulatory Landscape' (2011) 84 Compliance Officer Bulletin 1-33 whereby it was noted that 'branding the CMPA as a consumer champion would be inappropriate, confusing and potentially dangerous. The job of a regulator is to ensure that regulation is effective and proportionate. That requires a balance between preventing abusive behaviour and ensuring that regulation does not impose excessive costs and restrictions. See also Nathan Willmott, 'Equipping the Modern Regulator: Assessing the New regulatory Powers under the Financial Services Act 2010' (2010) 78 Compliance Officer Bulletin, 1-28. 
controversial. ${ }^{154}$ Following the OFT "Competition in the Profession's Report" in 2000, ${ }^{155}$ the Law Society changed its regulations to allow referral fees in 2004, as this form of restriction was regarded as being anticompetitive. ${ }^{156}$ The rationale was that there was no apparent reason why an out-right ban on referral fees could be regarded as proportionate. It was argued that they would benefit access to justice by providing a less intimidating way of accessing lawyers. Five years after the Law Society relaxed its regulatory rules to allow referral fees, the Law Society voted to support a ban on referral fees. ${ }^{157}$ In the interim period an industry of claims management companies emerged. Certain law firms were buying blocks of claims that had been assembled by claims management companies. The Law Society's objections to referral fees were based on the following arguments: (1) The financial relationship between lawyers and introducers had the potential to lead to the needs of the referrer being placed above those of the client; (2) Law firms having become reliant on buying work from claims management companies had framed their business plans accordingly meaning that, through competition, claims management companies would sell work to the highest bidder. (3) Given that there is no certainty that a claim would be successful, and that the cost of the referral fee had to be recovered, referral fees added unnecessary costs to legal advice because a percentage of cases have to be won to compensate for those that have not. This, it was argued, could lead to lower quality advice as lawyers would be forced to cut corners to deliver advice and make profits. (4) A further argument was made that referral fees cut choice and access to justice by pushing consumers to use referred lawyers, as opposed to the most appropriate lawyers and/ or the

\footnotetext{
154 John Cooper, 'Referral Fees: Corrupt and Criminal' (2012) 176 Criminal Law and Justice Weekly 29; Katherine Dillon, 'Referral Fees and PI- the Way Forward?’ (2007) 4 Journal of Personal Injury Law 324.

155 OFT, Competition in Professions (OFT328, 2001).

156 Paula Rohan, 'Law Society Votes to Allow Referral Fees' (Law Society Gazette, 9 January 2004) <http://www.lawgazette.co.uk/news/law-society-votesallow-referral-fees-0> accessed 22 July 2014; Law Society, 'Referral Fees: An Overview' (The Law Society, 7 March 2006)

<http://governance.lawsociety.org.uk/secure/meeting/201322/SRA_Board_Paper _Public_Item_8_-_Referral_Fees.pdf $>$ accessed 22 July 2014

${ }^{157}$ James Dean, 'Law Society Council Votes Against Referral Fees' (Law Society Gazette Online, 2009) <http://www.lawgazette.co.uk/news/law-society-councilvotes-against-referral-fees> accessed 22 July 2014.
} 
best quality. ${ }^{158}$ The Law Society noted that a number of personal injury claims were dealt with by what have been termed "Personal Injury factories", employing a largely unqualified workforce. Overall the Law Society deemed that referral fees were doing untold damage to the reputation of the profession. ${ }^{159}$

In light of the new competitive environment brought about by the LSA 2007 and changes to legal aid funding that lawyers were faced with in 2009, it would be easy to dismiss the claims of the Law Society as reactionary and protectionist. However, in 2009 Lord Justice Jackson, undertaking a comprehensive review of civil litigation costs, advocated a ban on referral fees in personal injury cases for similar reasons to those outlined above. The report noted the inappropriateness of having victims of personal injuries traded as commodities. The report also argued that the culture of ambulance chasing had led to the commoditisation of claims ${ }^{160}$ leading to serious problems in the insurance industry. This was largely because the merits of claims were seldom assessed until they reached the hands of lawyers, and that even then many claims were pursued regardless. ${ }^{161}$ The cost of litigation meant that it was more cost effective for many insurance companies to settle cases rather than try and defend them. The problem was that this had resulted in an inexorable rise in insurance premiums. The report also highlighted the fact that referrers simply referred cases to the highest bidder and that this was inappropriate from the perspective of justice. ${ }^{162}$

The LSB began a review of referral fees in 2009 in response to the Law Society's vote to ban them. In 2010 the LSB published proposals for a consultation. It then published the consultation. The executive summary in the consultation document noted that the LSB considered neither an outright ban nor a "free for all" to be appropriate, but that there should be increased transparency. ${ }^{163}$ It would appear that the Board had made up its

\footnotetext{
158 The Law Society, 'Law Society Statement on Referral Fees' (The Law Society, 2011) <http://www.lawsociety.org.uk/news/press-releases/law-society-statementon-referral-fees/> accessed 22 July 2014.

159 Dean (n 157); The Law Society (n 158).

160 Review of Civil Litigation Costs: Final Report, (TSO, January 2010) <http://www.judiciary.gov.uk/Resources/JCO/Documents/Reports/jackson-finalreport-140110.pdf $>$ accessed 23 July 2014, 204-6.

161 Ibid.

162 Ibid.

163 Legal Services Board, 'Referral Fees, Referral Arrangements and Fee Sharing - Discussion Document on the Regulatory Treatment of Referral Fees, Referral Arrangements and Fee Sharing' (LSB, September 2010)
} 
mind before publishing the consultation. Prior to publishing this consultation the LSB had asked the LSCP to consider the subject. They produced a report, ${ }^{164}$ drawing on research conducted by Vanilla Research. ${ }^{165}$ This research had suggested that there was maybe a case for requiring more transparency when a client's referral would result in the introducer receiving a payment. The substance of Vanilla Research's research was a relatively small number of interviews and group discussions based on perceptions and preferences about making a claim. Based on this arguably limited research the LSCP made a case that referral fees should be retained. They did not seek to assess anything other than the interests of the consumer. The LSB also commissioned Charles River Associates ${ }^{166}$ to consider a cost benefit case for referral fees. Their methodology was based on market failure theory. Charles River Associates reported no problems with conveyancing referrals. They found no evidence to suggest that referral fees in personal injury cases were causing consumer detriment and advised that referral fees were unlikely to be problematical. ${ }^{167}$ The cost benefit analysis included in the report makes no reference to factors extending beyond consumer detriment and the consumer interest. ${ }^{168}$

The LSB sought views on its 2010 consultation and on the conclusions that it had initially arrived at, based on the LSCP's opinion and the Charles River report. A report combining these findings, with

$<$ http://www.legalservicesboard.org.uk/what_we_do/pdf/20100929_referral_fees. pdf $>$ accessed 29 July 2014.

${ }^{164}$ Vanilla Research is a small market research consultancy specialising in consumer perceptions. Vanilla Research, 'Referral Arrangements Research' (Vanilla Research, March 2010)

$<$ http://www.legalservicesconsumerpanel.org.uk/publications/research_and_repor ts/documents/VanillaResearch_ConsumerResearch_ReferralArrangements.pdf accessed $>$ accessed 29 July 2014. This report was based on ten group discussions with consumers or potential consumers.

165 Legal Services Consumer Panel, 'Referral Fees' (LSCP, May 2010) $<$ http://www.legalservicesconsumerpanel.org.uk/publications/research_and_repor ts/documents/ConsumerPanel_ReferralArrangementsReport_Final.pdf > accessed 29 July 2014.

${ }^{166}$ Charles River Associates 'Cost Benefit Analysis of Policy Options Related to Referral Fees in Legal Services' (Charles River Associates, May 2010) $<$ http://governance.lawsociety.org.uk/secure/meeting/185852/Consultant_report_ on_referral_fees_May2010.pdf > accessed 22 July 2014.

${ }^{167}$ Ibid.

${ }^{168}$ Charles River Associates (n 166). 
those of various stakeholders was published in September 2010. ${ }^{169}$ In this report, the LSB posed a series of further questions and asked for stakeholders to respond. ${ }^{170}$ Drawing heavily on the LSCP and the report prepared by Charles River, the LSB argued that it had developed robust evidence upon which to base its opinions. The final decision of the LSB was to not recommend banning referral fees, but instead to introduce requirements for transparency. The requirement for transparency meant that consumers would have to be apprised of the fact that a referral fee had been paid by a lawyer to the intermediary that introduced the lawyer to the consumer. This decision was published in May 2011. ${ }^{171}$ The recommendation for enhanced transparency has since been regarded as both aspirational and unworkable. ${ }^{172}$ However, the extent to which the LSB followed the advice proffered by the LSCP is clear to see from the following excerpt from a letter sent by Chairman David Edmonds to the then Chair of the LSCP, Diana Hayter:

"Your advice to us has been invaluable and was central to the proposals we consulted on in September. Your advice set out a persuasive analysis of the impact of referral fees on consumers and was backed by empirical research which has ensured that consumers' views were fed into the process directly. Your conclusion of 'reveal, regulate so retain' was the basis for our discussions and has remained fundamental to our final decisions on referral fees.” ${ }^{173}$

${ }^{169}$ Legal Services Board, 'Referral Fees, Referral Arrangements and Fee Sharing - Discussion Document on the Regulatory Treatment of Referral Fees, Referral Arrangements and Fee Sharing' (LSB, September 2010) $<$ http://www.legalservicesboard.org.uk/what_we_do/pdf/20100929_referral_fees. pdf> accessed 27 July 2014.

${ }^{170}$ Ibid.

${ }^{171}$ Legal Services Board, 'Referral Fees, Referral Arrangements and Fee Sharing Decision Document' (LSB, May 2011)

$<$ http://www.legalservicesboard.org.uk/what_we_do/consultations/closed/pdf/201 10527_referral_fees_decision_press_release_final4.pdf> accessed 24 July 2014

172 Legal Futures, 'Straw: Legal Services Board report on referral fees was "gobbledegook", (Legal Futures, 29 September 2011) < http://www.legalfutures.co.uk/news/straw-Legal Services Board-report-onreferral-fees-was-gobbledegook> accessed 12 July 2014.

173 Legal Services Board, 'Letter from David Edmonds to Dianna Hayter on Referral Fees’ (LSB, 26 May 2011)

<http://www.legalservicesboard.org.uk/what_we_do/consultations/closed/pdf/201 10526_letter_david_edmonds_to_Dianne_Hayter.pdf> accessed 14 August 2014. 
On the 9 September 2011, the Government announced that referral fees in personal injury cases should be banned and that it was taking steps to bring about legislation to this effect. In a written ministerial statement, Jonathan Djanogly ${ }^{174}$ noted that the current arrangements had led to the growth of an industry that actively encouraged individuals to bring cases, regardless of the merits of their claim, and spoke of the effect on insurance premiums. He also spoke of the serious effect on the reputation and integrity of the legal profession. ${ }^{175}$ On 26 October 2011, Ken Clarke ${ }^{176}$ announced that he was tabling amendments to the Legal Aid, Sentencing and Punishment of Offenders Bill to ban referral fees in connection with personal injury claims. ${ }^{177}$ The amendment was agreed to. Section 56 of the Legal Aid, Sentencing and Punishment of Offenders Act 2012 now prohibits referral fees in personal injury claims. ${ }^{178}$ The Law Society and the Bar, along with others, including a cross section of the Government, remains committed to banning referral fees outright. ${ }^{179}$

It is clear from the foregoing that the combination of the LSCP's research and the cost benefit analysis undertaken by the economic and business consulting firm, Charles River Associates, was deemed sufficient to address the public interests associated with referral fees. ${ }^{180}$ In particular, in arriving at their decision, the LSB noted:

"our scrutiny has been focused on the regulatory treatment of referral fees, assessed against the regulatory objectives set out in Section 1 of the Legal Services Act 2007. We do not offer a view

\footnotetext{
${ }^{174}$ Parliamentary Under- Secretary of State for Justice.

${ }^{175}$ Ministry of Justice press release, Better protection from intruders and excessive compensation costs, 26 October 2011.

$<$ http://www.justice.gov.uk/news/features/feature261011a> accessed 24 July

2014.

${ }^{176}$ Secretary of State for Justice and Lord Chancellor.

177 HC Deb 1 November 2011 cc822-849.

${ }^{178}$ Legal Aid, Sentencing and Punishment of Offenders Act 2012 c 10 pt 2 s 60

179 The Bar Council, 'Bar Council Welcomes move to ban Referral Fees but calls

for Further Action' (Bar Council, 9 September 2011)

$<$ http://www.barcouncil.org.uk/media-centre/news-and-press-

releases/2011/september/bar-council-welcomes-move-to-ban-referral-fees-but-

calls-for-further-action/> accessed 22 July 2014;

Catherine Baksi, 'OFT Calls for Referral Fee Payment Regulation' ( Law Society Gazette, 25 ${ }^{\text {th }}$ February 2014) <http://www.lawgazette.co.uk/news/law-societycouncil-votes-against-referral-fees> accessed 22 July 2014.

${ }^{180}$ Legal Services Board (n 171).
} 
on any wider public policy arguments for their retention or abolition." 181

This assertion, coupled with the consumer and economic research relied on by the LSB rather begs the question what does the LSB actually consider the regulatory objective of 'protecting and promoting the public interest' to involve? There was no reference to the public interest in any of the documents published by the LSB. The force of the arguments from the Law Society, The Bar, ${ }^{182}$ Lord Justice Jackson, The Association of British Insurers, the former Lord Chancellor Jack Straw ${ }^{183}$ and, in part, the Office of Fair Trading were apparently not considered. Arguably they reflected the public interest, whereas the LSB seemingly favoured the findings of the LSCP and the research from Charles River Associates. ${ }^{184}$ This assertion is bolstered by the following response to a question posed by a member of the House of Commons Justice Committee regarding the LSB's approach to referral fees and whether the Board had been complacent in the approach it had taken to referral fees. David Edmonds, Chair of the Board responded as follows:

"I think 'complacency' is not a word I would use. When my Board was set up, we instituted a consumer panel that did a significant tranche of research into this area and produced a report that said they could not see consumer detriment arising from the administration of referral fees in the legal services sector. The Secretary of State and Parliament took a different view in terms of

\footnotetext{
181 Ibid.

182 Bar Council, 'Joint Response of the Bar council and Criminal Bar Association to the Legal Services Board Discussion Document on the Regulatory Treatment of Referral Fees, Referral Arrangements and Fee Sharing' (Legal Services Board, 21 December 2010)

<http://www.legalservicesboard.org.uk/what_we_do/consultations/closed/pdf/join t_response_of_the_bar_council_and_criminal_bar_association.pdf > accessed 29 July 2014.

183 Legal Futures (n 172).

${ }^{184}$ Paradoxically, despite the ban, it is likely that is that Alternative Business Structures, it will be easy to circumvent the referral fee ban in the future. John Hyde, 'SRA Powerless to Stop ABS Circumventing Referral Fee Ban' (Law Society Gazette, 13 June 2012) <http://www.lawgazette.co.uk/news/srapowerless-stop-abss-circumventing-referral-ban> accessed 29 July 2014.
} 
personal injury, and that part of the referral fee process has now been banned.” 185

"I am both defensive and protective of our stance on referral fees. As a regulator with an interest in economic regulation, I like to see markets operating in a way in which markets can operate,_which is that referrals are made, satisfactory solutions are found and you don't intervene where there is no evidence that you should intervene. I guess there is a degree not of complacency but of agnosticism on the part of my board, fuelled by the report of my own consumer panel. If anyone was going to complain about, or find evidence of, consumer detriment, it would be in the research that they commissioned in this area, and they didn't find any. That is why, after a lengthy debate, my board took the decision that we did take. As you have seen, the Minister took a different view over personal injury." 186

This response evidences the strong ideological commitment that the LSB has adopted towards the market. It also draws attention to the close connection between the LSB and the LSCP. The attention seemingly paid to the LSCP's findings affirms, in part, some of the incidents of cultural capture outlined in this paper. In terms of the ingredients that Carpenter suggests for a finding of capture, if the fact that the Legal Aid and Sentencing and Punishment of Offenders Act 2012 is an expression of the public interest, then the regulatory decisions taken by the LSB shows a policy shift away from the public interest and towards industry (special) interest. The position adopted by the LSCP, their research and the magnitude of their desire to see referral fees not banned shows action and intent by a special interest in pursuit of the policy shift sufficiently effective to have plausibly caused an appreciable shift in the regulator's (LSB) position.

\section{Lay Chairs of Approved Regulators Regulatory Boards}

The second decision taken by the LSB relates to the changes that they have made to the Internal Governance Rules for all Authorised Regulators. Prior to the change of these rules on the 20 February 2014 the Authorised Regulators were able to appoint to their regulatory boards, following general principles, anyone. That is to say that there was no bar

${ }^{185}$ House of Commons Justice Committee, The Operation of the Legal Services Board (2013 HC 963-1) 14.

${ }^{186}$ Ibid. 
on who the chairperson might be - provided that they were qualified in terms of the skills, experience and qualifications. Therefore, the Chair of the regulatory boards might be a lawyer, it might be a non-lawyer, it might be a former practitioner whose days of practising were over as they progressed their career. Now, the Chair of the Boards can only be a layperson. Lawyers, and those with a background in the law need not apply. A suggestion that the Chairperson of Approved Regulators Boards must be a lay person was made in 2009 by the LSCP without any empirical or theoretical basis. ${ }^{187}$ The suggestion was not adopted by the LSB who cited it, at the time, as "a step too far." 188 As a result of what the LSB perceived as difficulties dealing with the SRA \& BSB in September 2013 they mooted a change of the Internal Governance Rules. The then Strategy Director, Crispin Passmore, presented a paper at the LSB Board on the 11September $2013^{189}$ where he explained the following:

"The LSB has been concerned that the regulators are not consistently committed to the liberalisation of their regulatory approaches. Whilst the key regulators have taken significant steps forward in terms of allowing ABS, shifting their models towards outcomes and re-focusing on risk based supervision, progress is still held back by traditions of barriers to entry and cultural ties to each regulator's 'bit' or title within the legal profession. This manifests in a number of ways in both policy substance and governance arrangements." ${ }^{190}$

187 Dianne Hayter, 'Response to the LSB Consultation on 'Internal Governance \& Practising Fees Rules’ (LSCP, 30 October 2009)

$<$ http://www.legalservicesconsumerpanel.org.uk/publications/consultation_respo nses/documents/2009-10-30_LSB_ConsultationInternalGovernanceRules.pdf> accessed 17 August 2014;

188 Crispin Passmore, 'Lay Chairs of Regulatory Boards' (LSB Board Meeting Papers, 11 September 2013)

<http://www.legalservicesboard.org.uk/about_us/board_meetings/pdf/13_59_chai rs_of_regulatory_bodies.pdf $>$ accessed 15 August 2014, 4.

189 Ibid.

190 Passmore (n 188) The Paper cites the following as reasons for the rule change: 'SRA reluctance to remove separate business rule; SRA approach to in-house solicitors ;SRA approach to multi-disciplinary partnerships; SRA pace of ABS authorisation and over emphasis on looking like they are controlling entry (when in actual fact less than 5 ABS licence have been refused); SRA and others' resistance to single appeals mechanism ;BSB reluctance to embrace non-barrister leading entities; BSB refusal to enforce against outcomes; Regulators' scepticism about data transparency in general and failure to make the data they have in a 
He went on to further note that:

"The Executive assesses that this reticence to embrace the better regulation principles can put the regulatory objectives at risk. In particular, the continuing tendency to threaten innovation and undermine competition, thus limiting consumer choice and compromising access to justice” 191

Mr Passmore also picked up on the attacks that the LSB had received about its approach to regulating. One of the most outspoken critics of the LSB's approach has been Baroness Ruth Deech, who, as it happens, has for the last 5 years been Chairwoman of the Bar Standards Board:

"The Board may also wish to note the level of commentary about the LSB's relentless focus on consumer interests. This has been described as a 'cult of consumerism' and that an 'excessive focus on the consumer interest may be to the detriment of the professional interests and standards upheld by the lawyers'”. ${ }^{192}$

The following quote from Mr Passmore's paper leaves the motive behind the restriction on allowing lawyers to become the Chairperson of the Approved Regulator’s Board in little doubt.

"The question is whether further changes to Board composition would help build greater proactivity in this area on the part of regulators themselves. Overly strong ties to history, culture and practice of self regulation by each part of the regulatory community are a significant drag on regulators complying with the better regulation principles and thus may put the regulatory objectives at risk. It therefore seems probable that the tendency of the regulators to hold on to a 'what they know' preference would be diminished by insisting on 'a fresh pair of eyes' at chair level,

range of areas widely available to enable independent analysis (so called big data analysis) ;Regulators' handbooks remaining complicated and prescriptive; Tendency to offer very detailed guidance in relation to changes which can be taken as mandatory; Tendency to involve complex sub-committee structures to scrutinise the micro- rather than macro - impact of proposed changes.'

${ }^{191}$ Ibid.

192 Ibid. 
provided that the boards as a whole have the right balance of skills and knowledge around the table.” 193

These statements, along with others made by the LSB, ${ }^{194}$ dismissing the points made by members of the legal profession, does signal a rather narrow minded approach to discourse and decision making. Lord Neuberger has made the point that it is a rather peculiar state of affairs to dismiss points that have been constructively and intelligently made by educated, qualified people, who are presumably capable of understanding the boundaries of public life and suppressing self - interest. ${ }^{195}$ In all of this - there is a delicious irony that Baroness Deech has had a very successful career outside of the law, in public life, choosing never to practise as a lawyer. She would, now, on a very minor technicality be prevented from being Chairwoman of the BSB under the rules introduced by the LSB in February 2014. However, to all intents and purposes she is cut from the same cloth that many definitively lay chair people are cut from.

What is interesting to this paper is how the policy articulated in Crispin Passmore's briefing, furthering the ideas suggested by the LSCP was translated into a regulatory decision, which as noted, was adopted. The following tracks the developments. Further to a resolution by the LSB in October 2013 a consultation was launched on a fast track process, meaning that there would only be 6 weeks for consultees to respond. The consultation closed on the $19^{\text {th }}$ November 2013. 14 of the 17 respondents to the consultation indicated strong or very strong opposition to the proposed rule change. ${ }^{196}$ Two of the three who agreed with the rule

\footnotetext{
193 Ibid.
}

194 'We want \{legal professions\} regulators to step back from dictating the services offered and the structures of businesses operating in the legal services market to allow market forces to play a greater role. This we believe will help create a legal services market that is the right size for consumers.' David Edmonds, 'Regulatory Standards and Assessing Regulatory Performance' (Legal Compliance Bulletin, 2012)

$<\mathrm{http}$ ///www.legalservicesboard.org.uk/news_publications/speeches_presentation s/2012/legal_compliance_bulletin_article_issue_20_july_2012.pdf> accessed 22 July 2014.

${ }^{195}$ Neuberger, (n 40)

${ }^{196}$ LSB, 'Submissions Received to the Consultation on Lay Chairs for Front Line Regulators' (LSB, 2013)

$<$ http://www.legalservicesboard.org.uk/what_we_do/consultations/closed/Submis sions_Received_To_The_Consultation_On_Lay_Chairs_For_Front_Line_Legal_ Regulators.html> accessed 14 July 2014. 
change were Which? and the LSCP. It is perhaps no surprise that the LSCP agreed, given that they were the intellectual brainchild of the ideas set out in the LSB's position paper. ${ }^{197}$ No clearer evidence is forthcoming than the following two statements made by the LSB that they had no evidence for this statutory change. This paucity of evidence was picked up by the 14 consultees who did not agree with the LSB.

\begin{abstract}
"We acknowledge that this was ultimately a matter of judgement based on our nearly four years of experience rather than on quantifiable evidence. Indeed, the very nature of the issues being considered here makes it unlikely that quantifiable evidence would be available" 198

“The proposed change was built on the LSB's view that although the AARs have made significant progress by accepting the principle of independent regulation and structurally separating regulatory functions out from their representative arms, the regulatory bodies remain tied too closely to the individual branches of the profession that they oversee.”199
\end{abstract}

It takes something of a leap of faith for a regulator who prides itself on being an "evidence based regulator" to jump from no evidence to arrive at the foregoing statements. It is suggested that the LSB saw an opportunity to speed up the pace of change in the legal services market as the terms of office of the Chairs of the SRA and BSB end in December 2014. This is aptly demonstrated in the following statements:

"In consultation we highlighted our view that this proximity is detrimental to both the public and consumer interest. We also

197 LSB, 'Chairs of Regulatory Boards - Consultation on an Amendment to the Internal Governance Rules to Require that the Chairs of the Boards of the Regulatory Arms of Each Applicable Approved Regulator be a Lay Person' (LSB, 2013)

<http://www.legalservicesboard.org.uk/what_we_do/consultations/pdf/lsb_consul tation_on_lay_chairs_08_10_13.pdf> accessed 16 August 2014.

198 LSB, 'Chairs of Regulatory Boards, Summary of Responses, Decision Document on a Proposed Amendment to the Internal Governance Rules to Require that the Chairs of Boards of the Regulatory Arms of Each Applicable Approved Regulator be a Lay Person' (LSB, 20 February 2014) <http://www.legalservicesboard.org.uk/what_we_do/consultations/closed/pdf/201 40219_LSB_Lay_Chairs_Summary_Of_Responses_And_Decision.pdf $>$ accessed 14 July 2014, 7.

199 Ibid 6. 
outlined our view that overly strong ties to the history, culture and rules of professional self- regulation within specific sub-groups can act as a significant drag on the better regulation principles and therefore put the regulatory objectives at risk. In particular this negatively impacts on the objective of promoting competition in legal services in order to improve innovation, value, consumer choice and therefore access to justice.” 200

"Further, we outlined our view that requiring the chairs of the regulatory boards to be lay would be likely to provide a proportionate route to greater regulatory independence. In proposing this change we acknowledge the crucial role played by chairs in leading their boards. In many cases, an inevitable effect of membership of a profession will be to influence behaviour when chairing a regulator. Given the importance of the chair and the greater time and support s/he has to shape discussion and consider issues, this influence could be disproportionately important.” 201

Given the LSB holds itself out to be an evidence based regulator it is strange that they did not consult any evidence. It is rather questionable why a much broader body of literature on the subject was not considered. This literature draws attention to the way in which lay involvement can, and does skew the decision making process of a board. A portion of this work specifically addresses the questions of how lay involvement, especially where understanding of the matter at hand is important, contributes to ineffective decision making. ${ }^{202}$

The timing of the LSB's decision also raises questions about its attitude to regulatory decision making. At the same time that the Board

${ }^{200}$ Ibid 6.
${ }^{201}$ Ibid 6.

202 Christine Hogg and Charlotte Williamson, 'Whose Interests Do Lay People Represent? Towards an Understanding of the Role of Lay People as Members of Committees' (2001) 4 Health Expectations 2; William Rothstein and Linh Phuong, 'Ethical Attitudes of Nurse, Physician, and Unaffiliated Members of Institutional Review Boards’ (2007) 39 Journal of Nursing Scholarship 75; Guy Holburn and Richard Van den Bergh, 'Consumer Capture of Regulatory Institutions: The Creation of Public Utility Consumer Advocates in the United States' (2006) 126 Public Choice 45; Orit Dayagi-Epstein, 'Representation of Consumer Interests by Consumer Associations - Salvation for the Masses? (2007) 3 The Competition Law Review 209; Les Carlson, 'Use, Misuse, and Abuse of Content Analysis for Research on the Consumer Interest' (2008) 42 The Journal of Consumer Affairs 100. 
was pursuing these changes, a high profile story was unravelling at the CO-OP which revealed some serious problems of lay involvement in boards, and the problems that a Lay Chair can bring. It is ultimately not good practice to pick on individual stories as evidence of anything. However, given the fact that 2 high profile investigations ${ }^{203}$ were commissioned investigating the governance arrangements of the CO OP, it might have been pragmatic to reflect on these findings - which, as it happens, drew attention to the problems brought about by an unqualified and largely lay Board with a lay Chair. ${ }^{204}$

This example demonstrates a narrowness of approach by the LSB and a wholesale casual connection between the policies initiated by the LSCP - right the way through to execution, despite vociferous opposition by those who responded to the consultation. It is possible to detect right through the decision document, published by the LSB, that actually what it wanted to do was to pursue its agenda without steadfast opposition to its plans. The document cites a rich culture and tradition of the professions as reasons that progress is delayed. This in a way demonstrates a counter cultural ideology and some of the features of cultural capture.

\section{Statutory Guidance and the Legal Education Training Review (LETR)}

The third decision taken by the LSB considered by this paper relates to its decision to use s 162 LSA 2007 to produce statutory guidance on how the "Approved Regulators" should make regulatory arrangements for education and training. The background to the LETR, in and of itself, tells a story. The LSB originally planned to conduct the review, however, it

203 The Co-operative Group, 'Report of the Independent Governance Review The Co-operative Group’ (Lord Paul Myners, 7 May 2014) <http://www.cooperative.coop/PageFiles/989348879/Report_of_the_Independent_Governance_R eview.pdf $>$ accessed 14 July 2014; The Co-operative Group, 'Failings in Management and Governance - Report of the Independent Review Into the Events Leading to the Co-operative Bank's Capital Shortfall' (Sir Christopher Kelly, 30 April 2014) 'http://www.thekellyreview.co.uk/documents/168461-07Kelly\%20Review-FINAL\%20REPORT-30APR14.pdf> accessed 14 July 2014.

204 The Kelly Report is replete with criticisms about the lay Board - which he asserted did not fully understand the requirements of a regulated bank (page 9), that the Board was oblivious to a number of issues (page 9), that there was a failure of stewardship which was an inevitable consequence of the limited relevant experience of the individual Board members, that there was a serious problem because the CBG failed to have relevant banking experience (page 10), that the Board was hampered by the lack of banking experience of the Chair page 11 . 
was persuaded to let the SRA, BSB and the as then ILEX professional standards board to take the lead under the LSB's oversight. ${ }^{205}$ It has been argued that this change occurred amidst allegations that the LSB was at risk of going beyond its oversight role. ${ }^{206}$ The then Chairman of the LSB set out his support and expectations for the report in the annual Lord Upjohn Lecture. ${ }^{207}$ The LETR took longer than expected to produce its final report. During the research phase many consultations and calls for evidence were made. ${ }^{208}$ Throughout the research phase the LSCP made a formal response to the consultation. ${ }^{209}$ This response by the LSCP set out a powerful vision for what education and training should look like. In addition, the LSCP took the liberty of writing to the head of the LETR research team, Professor Julian Webb, urging the team to "put the interest of consumers at the forefront of its recommended scheme". Moreover, the LSCP urged the team to take the once in a generation opportunity to produce a 'bold blueprint' for change in legal education and training. ${ }^{210}$ They asserted that 'vested interests' were striving to water it down. ${ }^{211}$

205 Legal Futures, 'Edmonds to Back Education and Training Review as LSB Role is Curbed’ (Legal Futures, 18 November 2010)

$<$ http://www.legalfutures.co.uk/latest-news/edmonds-to-back-education-andtraining-review-as-lsb-role-is-curbed/print/> accessed 14 August 2014.

206 Ibid.

207 David Edmonds, 'Training the Lawyers of the Future - A Regulator's View' (LSB, 19 November 2010)

<http://www.legalservicesboard.org.uk/news_publications/speeches_presentation s/2010/de_lord_upjohn_lec.pdf> accessed 16 August 2014.

208 LETR, 'Setting Standards, The Future of Legal Services Education and Training Regulation in England and Wales' (LETR, June 2013) 'http://letr.org.uk/wp-content/uploads/LETR-Report.pdf> accessed 16 August 2014.

${ }^{209}$ LSCP 'Response to the LETR Consultation on Legal Education and Training' (LSCP, 21 May 2012)

$<$ http://www.legalservicesconsumerpanel.org.uk/publications/consultation_respo nses/documents/2012-05-21LETRsubmission.pdf> accessed 17 August 2014.

210 Elisabeth Davies, 'Letter from Legal Services Consumer Panel to Prof Julian Webb - Legal Education Review Team' (LSCP, 23 October 2012) $<$ http://letr.org.uk/wp-content/uploads/Legal-services-consumer-panel1.pdf> accessed 14 August 2014.

211 Legal Futures, 'Be bold and Ignore the Vested Interests LETR Told' (Legal Futures, 25 October 2012) <http://www.legalfutures.co.uk/latest-news/be-boldignore-vested-interests-letr-told/print/> accessed 14 July 2014. 
The LETR team published its findings on 25 June $2013^{212}$ and it is no understatement that the reaction to it was one that was damped with faint praise. ${ }^{213}$ Whilst it was a thoroughly researched document, producing a range of sensible recommendations, it did not, and was perhaps never going to, seize the once in a generation opportunity to fundamentally change legal education and training that the LSCP would have liked. Arguably the research did not suggest that this was necessary. In many regards the current system is not as broken as some might perceive and thus does not require the sorts of developments argued by some as necessary. Writing after the publication Neil Wightman, for and on behalf of the LSCP argued that a major opportunity had been missed - asserting that "it would have been wonderful to report that the way forward is to redesign legal education and training around the consumer". He should perhaps be reminded that the law and its practise do not revolve solely around the consumer (however the consumer's interest might be constructed). The rule of law, the public interest and a host of other imperatives are, it is suggested, equally important factors for consideration. The LSCP would have liked to have seen the following: active quality assurance by regulators, periodic re-accreditation of practitioners, on-going competency checks, updated professional service standards and skills, training and education designed and delivered around the consumer, a system of CPD that is fit for purpose and the creation of new access points to improve social mobility. ${ }^{214}$ The reason for pointing this out is that the LSCP were clearly disappointed with the LETR as were the LSB. In a briefing paper supplied to the LSB's Board Meeting on the 24 July 2013 it noted:

"The final report starts from the position that the current system of education and training is fit for purpose. It therefore proposes incremental change, backed up by the necessary infrastructure to enable more significant change over time. This conclusion has been reached on the basis of the evidence provided to the review

\footnotetext{
212 LETR (n 208)

${ }^{213}$ See in particular Richard Moorhead, 'Why Everyone is Happy and No One is Smiling' (Lawyer Watch, 26 June 2013)

$<$ http://lawyerwatch.wordpress.com/2013/06/26/letr-why-everyone-is-happy-andno-one-is-smiling/> accessed 16 August 2014.

214 Neil Wightman, 'LSCP Panel Member Neil Wightman's Reaction to the LETR.’ (LSCP, 25 June 2013)

<http://www.legalservicesconsumerpanel.org.uk/how_can_we_help/blog/blog_en try_guest_june_2013.html> accessed 16 August 2014.
} 
which focuses heavily on the views of the profession. While we would support the need for evidence there is a perception that the report and its conclusions rely too heavily on the views of the profession and do not give enough weight to the consumer perspective (as is the view of the Legal Services Consumer Panel)."215

As statements go - the one pertaining to the fact that the evidence relied upon by the LETR is heavily focused on the views of the profession is open to question. A casual perusal of the robust academic sources relied upon by the LETR dispels this notion. This is before the wealth of submissions to the various calls for evidence and consultations are considered. In attempting to explain this statement - the LSB's subsequent actions tell its own story. In the LSB's Board meeting that the above briefing paper was received at, the Board resolved to propose draft statutory guidance regarding education and training. This draft statutory guidance was to be produced for its September Board Meeting. ${ }^{216}$ At the September board meeting of the LSB it resolved to put this draft statutory guidance out for consultation. ${ }^{217}$ The rationale for this statutory guidance was as follows:

"In our view statutory guidance provides a clear and transparent way to set out the LSB's views in this area. It also provides a solid basis for which they could review progress or take action if they found evidence of detriment to the regulatory objectives or better regulation principles." ${ }^{218}$

215 Crispin Passmore and Alex Roy, 'LETR Briefing Paper (13)54’ (LSB, 24 July 2014)

<http://www.legalservicesboard.org.uk/about_us/board_meetings/pdf/13_54_LE TR_report_briefing.pdf $>$ accessed 17 August 2014.

216 Ibid; Legal Services Board 'Minutes of a Meeting of the Legal Services Board on 24 July 2013’ (LSB, 26 July 2013)

$<$ http://www.legalservicesboard.org.uk/about_us/board_meetings/pdf/20130724_ minutes.pdf $>$ accessed 17 August 2014.

217 Legal Services Board 'Minutes of a Meeting of the Legal Services Board on 11 September 2013’ (LSB, 12 September 2013)

<http://www.legalservicesboard.org.uk/about_us/board_meetings/pdf/20130911_ minutes.pdf $>$ accessed 17 August 2014.

218 Emily Lyn, Crispin Passmore, Alex Roy, 'Legal Services Board Meeting Briefing Paper (13) 58’ (LSB, 11 September 2013)

$<$ http://www.legalservicesboard.org.uk/about_us/board_meetings/pdf/13_58_letr _consultation_paper.pdf> accessed 17 August 2014. See also LSB 'Increasing 
This statement, articulating the LSB's rationale, indicates that it wished to set out its own vision for how matters associated with legal education and training should develop. What is less clear is what robust evidence base led them to set out this vision. There is certainly no reference to research in any of the briefing papers, or the consultation documents produced by the LSB. The framing of this statutory advice also, as outlined above, provides the basis upon which, in the LSB's own words, momentum in this area might be maintained and a culture of change might be brought about. ${ }^{219}$ As clearly indicated, this statutory guidance is to be used by the LSB to assess the extent to which their vision is being pursued. The clear implication is that they intend to hold the Approved Regulators to account to their vision.

The draft statutory guidance was put out for consultation in September 2013. The period for consultation ended on the 11 December 2013. There were 16 responses to the consultation, 6 from the Approved Regulators, 6 from representative bodies, 2 from legal education providers and one from the LSCP. ${ }^{220}$ The majority queried whether there was any need for the LSB to take this action. Many respondents questioned whether issuing statutory guidance was a proportionate response for the LSB to take. On the 4 March, despite many serious points being raised by the respondents to the consultation, the LSB published, under s162 LSA 2007 - statutory guidance on education and training. ${ }^{21}$ Whilst as noted earlier on the LSCP has a wide range of ambitions when it comes to education and training - it is perhaps no surprise that the statutory guidance issued by the LSB reflects in a multitude of ways the ideas of the LSCP. The

flexibility in legal education and training Consultation on proposals for draft statutory guidance to be issued under section 162 of the Legal Services Act 2007' $<$ http://www.legalservicesboard.org.uk/what_we_do/consultations/closed/pdf/201 30918_consultation_paper_on_guidance_for_education_and_training_FINAL_fo r_publication.pdf > accessed 17 August 2014.

${ }^{219}$ Lyn (n 218).

220 Legal Services Board, 'Submissions Received to the Consultation on Proposals for Draft Guidance on Education and Training'(LSB, December 2013) $<$ http://www.legalservicesboard.org.uk/what_we_do/consultations/closed/Submis sions_Received_To_The_Consultation_On_Proposals_For_Draft_Guidance_On_ Education_And_Training.html $>$ accessed 17 August 2014.

${ }^{221}$ LSB, 'Guidance on Regulatory Arrangements for Education and Training Issued Under s 162 of the Legal Services Act 2007' (LSB, 4 March 2014) $<$ http://www.legalservicesboard.org.uk/what_we_do/consultations/closed/pdf/201 40304_LSB_Education_And_Training_Guidance_2.pdf $>$ accessed 17 August 2014. 
LSCP's ideas when it comes to education and training are set out in its submission to the LETR research team. Without reference to any real substantive research the LSCP sets out, in this document, a desire to see a future education and training system built around an activity-based authorisation regime for individuals and entities. ${ }^{22}$ In particular they frame their entire submission around 'activity based regulation,' 'reaccreditation' and 'regulation of entities.' ${ }^{223}$ The LSB's statutory advice, which sets out 5 outcomes, which are also qualified in some detail, produced by the LSB, reflects almost in its entirety these three themes, with some flourishes that mitigate some of the more controversial elements of the LSCP's suggestions. It is, however, clear that the intellectual bedrock of the LSB's vision rests quite firmly on that articulated by the LSCP. As acknowledged earlier in this paper this is to be expected as a result of the construction of the LSB and its consumer panel. The point at issue is, in the face of a robust piece of work conducted by the LETR team which laboured for 3 years to produce a report - where is the intellectual basis of the LSB's statutory guidance? Moreover, as outlined earlier the LSB and LSCP were clearly not convinced by the LETR report and its apparent neglect of the Consumer. The actions taken by the LSB, drawing on the LSCP's robust views in this area, once again suggest that the consumer it being prioritised ahead of at least thoughtful consideration of the public interest. Where the public interest lies in all of this is open for discussion, however, designing an education and training system around the consumer is, for a spectrum of reasons, unlikely to protect and promote the public interest.

\section{DISCUSSION}

The aforementioned three illustrations of the way in which the LSB has made decisions reveals, firstly, an instance in which the public interest was, by the LSB's own admission, not taken account of. Secondly, a decision that was taken by the LSB which, by its own admission, was based on little, to no, evidence. Thirdly, a decision was made in the context of education and training which was both un-evidenced and arguably un-necessary. What unites all three of these illustrations is the reliance placed on research or policy set forth by the LSCP to the LSB. In

\footnotetext{
${ }^{222}$ LSCP 'Response to the LETR Consultation on Legal Education and Training' (LSCP, 21 May 2012)

<http://www.legalservicesconsumerpanel.org.uk/publications/consultation_respo nses/documents/2012-05-21LETRsubmission.pdf> accessed 17 August 2014. 223 Ibid 4.
} 
considering the three elements of capture, discussed earlier on in this paper, it is difficult to conclusively arrive at an understanding of what the public interest is. This, as previously noted, requires further substantial investigation. However, in at least one of the cases, a clear alternative to the path preferred by the LSB was taken by the Government acting in a legislative capacity. They were robustly supported in this by a welter of other organisations and impartial commentators. As to the policy approach advocated by the LSB - this clearly favoured the LSCP's preferred policy outcome and a discernible move was made by the LSB away from the public interest as maybe otherwise understood. By virtue of the LSCP's expressed policy, it is clear that there was intent by them in favour of a special interest, purportedly representing the 'consumer interest.'

With regards to the second decision taken by the LSB, in light of the parameters of regulatory capture suggested at the beginning of this paper - it is slightly more difficult to make a clear determination on this. Firstly, understanding where the public interest lies is, as noted above a matter of some determination. This paper has clearly indicated that there is scholarship on the wisdom of lay boards in regulatory decision making. Doubt has been cast over whether lay boards and lay chair people are necessarily as ideal as some would promote them to be. The LSCP certainly set out their desire for lay chair persons of the regulatory boards a long time ago. It is unclear what their intellectual argument for this was. What is clear, however, is that the decision taken by the LSB on lay chairs favoured the LSCPs position on this matter. Given that the LSCP had a positive policy on this matter this demonstrates intent on their behalf to realise this change. Therefore, in this case, again, subject to a determination of the public interest, it appears that some of the conditions for finding capture are apparent in this situation.

Regarding the last example, again, the public interest in this context is a matter for some discussion. What is, however, clear is that the LSB clearly favoured the LSCPs policies in this area - and clearly developed their thinking together on this. This is, as clearly articulated, not reflective of the whole broad thrust of thinking and interests in this area. The LSCP has a clear policy to design education and training around the consumer. The mere fact that they negate to consider the public interest is a cause for concern. In a way this suggests that they are preoccupied with their vision and policies - absent any real theoretical or research backing. Moreover, their lack of appetite to take account of the range of other interests which are necessary to be considered, is concerning. The fact that the LSB's statutory guidance reflects in substance the policies of the LSCP demonstrates a move away from some important public interest considerations. 
In drawing the various strands of this paper together - when it comes to making a claim that the LSB has been captured; a number of considerations need to be born in mind. The first of which is that there are a range of structural factors which lead to the prioritisation of the consumer interest. It would be incorrect to hold the LSB accountable for following the letter of the LSA 2007. It would also be incorrect to hold the LSB accountable for setting up the LSCP and working with it. If anything, an allegation of consumer capture rests at the legislative stage - where it is arguable that the Government became captured by the consumer lobby and entrenched voices within Government who advocated the promotion of the consumer interest.

This paper has sought to explain the problems associated with the consumer interest and its promotion. Moreover, it has drawn on various critiques of commonly used economic methodologies used in decision making which promote a version of the consumer interest. This has, in part, illustrated some of the attendant dangers of promoting consumer orientated policies without thoughtful consideration of the public interest. The aforementioned economic methodologies appear not to take account of the public interest. The LSB appears to have struggled with conceptualising the public interest. In attempting to make a judgment as to whether the LSB has become captured by the consumer interest it is important to Carpenter's definition to discover whether special interests have actively and knowingly sought to move policy away from the public interest towards the consumer interest. The foregoing has illustrated that there is a close connection between the LSB and the LSCP. It has also shown that the LSB has a strong ideological bent and that the evidence to back up some of its policies is both formed by the LSCP and is wanting in some regards. It is plausible to suggest that the LSB believes that it is protecting and promoting the public interest through the decisions that it has made. It would also be a dramatic accusation to make that the LSCP actively wished to knowingly and actively advance policies away from the public interest. For this reason, and existing problems surrounding the public interest in the context of legal services, it would likely be a challenge to conclusively meet Carpenter's evidential burden for capture. If anything this paper charges both the LSCP and the LSB with failing to sufficiently get to grips with, and respect, the public interest.

In terms of making an assertion based around capture, Kwak's theories about cultural capture, McCarty's theories around capture and provision of expertise by interest, and Zingales' theories about economists capture - all provide promising routes of enquiry. As illustrated throughout this paper - a variety of pieces of evidence exist to suggest that these forms of capture might all exist. At present these remain 
suggestions and fuller examination needs to be made of each. It remains a theoretical issue for future resolution how each of these forms of capture are to be resolved with Carpenter's definition. The aspect of Carpenter's definition that requires intent on behalf of the interest group is difficult to rationalise with the theories posited by Kwak in the context of cultural capture. By its very nature culture does not necessarily manifest intention or a form of mens rea. Kwak's notion of cultural capture appears a particularly appealing way of explaining many of the approaches taken by the LSB. The way in which particular tools have been selected for decision making, the ideological predisposition of the member of the LSB, the proactive approach that the LSB have adopted, often in the face of expert comment advocating alternative approaches, all points to a general culture inside the regulator which prioritises the consumer interest. The pursuance of a consumer orientated set of policies is perhaps culturally no surprise.

\section{CONCLUSION}

This paper concludes, by suggesting that there is little prospect of the LSB changing its approach to the consumer interest. Sir Michael Pitt, the new Chairman of the LSB has re-affirmed the existing ideological predisposition of the LSB in a recent paper supplied to the LSB's May 2014 Board Meeting. He stated:

“The LSB has been criticised for its 'consumer obsession' by some of the regulators and indeed the senior judiciary. I am similarly obsessed and for me it is a starting point. We still have a market which is far too intimidating, too uniform and, in many cases, too expensive.” 224

"In the wider economy, customers are generally best served by well-functioning markets, with public interest safeguards and regulation targeted only where justified in light of the fundamental characteristics of the market (for example the inevitable disparities

${ }^{224}$ Sir Michael Pitt, 'LSB Strategy: Chair’s Perspective Paper 14(28)’ (LSB, 22 May 2014)

$<$ http://www.legalservicesboard.org.uk/about_us/board_meetings/pdf/20140522_

22_May_2014/14_28_LSB_Strategy_Chairs_Perspective.pdf $>$ accessed 19 August 2014, 2. 
in knowledge between consumers and the professionals they consult)"225

"I would like to think that every decision we make is informed by a "consumer interest" test of whether legal services are becoming more rather than less accessible. I believe there is much to be gained in this respect by learning from the Consumer Panel and the OLC who have access to significant evidence relating to consumer behaviours and experiences.” 226

In drawing together the various elements of this paper the following points can be made. Firstly, there are a number of robust reasons why regulating in the consumer's interest is not always a sensible thing to do. Secondly, there are a number of structural factors, inherent in the design of the LSA 2007 which led to a prioritisation of the consumer interest. This is compounded by modern decision making methods which inherently rely upon narrow decision making tools borrowed from crude and basic economics. For reasons to do with quantifying the public interest and apportioning an active intention on behalf of the consumer lobby to detract from the public interest - it is difficult to assert, according to the evidential burden set out by Carpenter that the LSB has been captured by the consumer interest and consumer lobby. It remains, however, plausible according to Kwak's theory of cultural capture that a more subliminal form of capture exists. The source of this capture is derived from a number of sources. Irrespective of this - the danger remains that regulation of the legal profession and legal services will continue, as it appears to have done since 2007, to advance an unreflective consumer orientated agenda. Aspects of this agenda might service the public interest. However, for reasons set out earlier to do with the problems of promoting an individual interests, which the market does - it remains much more than a possibility that the public interest is neglected. It remains imperative that greater focus is placed on the public interest such that this interest is not subordinated.

225 Ibid 2.

226 Ibid 3. 